\title{
THE SWEDISH LEGAL SYSTEM: AN INTRODUCTION
}

\author{
Bernard Michael Ortwein II*
}

\section{INTRODUCTION}

Culturally, the Swedish people are less inclined than U.S. citizens to resort to outside sources for help in solving their legal problems. In addition, when they do seek outside assistance they have a history of utilizing arbitration rather than litigation as their primary dispute resolution method.' One Swedish commentator reports that, in the private law area, only "[a]bout 20,000 to 25,000 ordinary civil cases, 15,000 small claims cases and 30,000 family law cases are dealt with by the courts each year."2 Litigation is more the exception than the rule and, in many ways, is considered the true alternative method of resolving disputes in Sweden. ${ }^{3}$ Generally, the Swedish people do not automatically think of seeking legal advice as problems arise. ${ }^{4}$ This attitude is fostered to some extent by the way the legal system is designed in Sweden as much as the cultural nature of the population. ${ }^{5}$

It has been stated that if one were to ask the average Swedish citizen what the "third branch of power" in their government might be, they would most likely reply "the press, the media. No one would think of the Courts."

* Professor of Law and Director of Foreign Programs, Suffolk University Law School. The author wishes to thank Deborah Starkman for her valuable assistance.

1. See Ulfe Franke, Arbitration, in SWEDISH LAW IN THE NEW MILLENNIUM 510, 510 (Michael Bogdan ed., 2000). One commentator has suggested that Swedish legislation contained arbitration provisions as early as the Fourteenth Century. See Ulfe Franke, Arbitration, in SwEDISH LAW A SURVEY 532, 534 (Hugo Tiberg et al. eds., 1994). Arbitration is particularly prevalent in the context of commercial matters, although "any question in the nature of a civil matter which may be compromised by agreement" is subject to arbitration by agreement of the parties. See id. In 1929, the Arbitration Act and the Act on Foreign Arbitration Agreements and Awards were enacted to help facilitate and encourage arbitration as the prime method of dispute resolution. See id. at 533.

2. Per Henrik Lindblom, Civil and Criminal Procedure, in SWEDISH LAW IN THE NEW MILLENNIUM, supra note 1, at 201, 217.

3. See Per Henrik Lindblom, Individual Litigation and Mass Justice: A Swedish Perspective and Proposal on Group Actions in Civil Procedure, 45 AM. J. CoMP. L. 805, 815 (1997). "[C]ivil courts are so seldom used that it sometimes seems more appropriate to regard the use of courts themselves as ADR." Id.

4. See id.

5. See id.

6. Lindblom, supra note 2, at 201. Obviously, the answer to this question would be different in America. Alexis de Tocqueville's comments in his seminal work, Democracy in America, that there are very few issues arising in the United States that do not sooner or later result in a judicial question, are perhaps more true today than they were when originally made. See Henry J. Abraham, The JUdicial PROCESS 19 (1998). 
This attitude is not unusual in countries with a strong civil law tradition. ${ }^{7}$ Typically, in civil law countries, the Judiciary is not on equal footing with the Legislative (Parliamentary) Branch in affecting the law. This may be changing in Sweden. At least one commentator has predicted that the role of the court will expand in the coming years. ${ }^{8}$ One question raised by this anticipated change is whether lawyers will be prepared to assume a larger and more influential role within the Swedish legal system as they become more involved in deciding the issues affecting the social, economic, and political life of Swedish citizens. ${ }^{9}$

Sweden, a Scandinavian country located in Northern Europe, approximates the State of California in size with a landmass of approximately 174,000 square miles. ${ }^{10}$ However, apart from its geographical area, Sweden is comparatively, sparsely populated with 8.8 million inhabitants or 52 inhabitants per square mile to California's approximately 217 inhabitants per square mile. ${ }^{11}$ This ratio is somewhat deceptive in that approximately one-half

7. The term civil law tradition or system is really a shorthand method of identifying a system of law that consists primarily of legislative or administrative enactments reduced to writing in codes as the supreme law of the country for all to see. There are a variety of terms that have been used interchangeably to identify this type of legal system, including statutory law system, code system, Roman system etc. Although there are some substantive and historical distinctions among these various terms they all have the same common theme. For purposes of this article, the shorthand term "civil law system" will be used throughout to identify those countries that have a strong legal "code" as their basis in contrast to the type of "common law" system in effect in America.

8. See Lindblom, supra note 2, at 202.

9. Kjell A. Modeer, The Ongoing Dream: Legal and Political Culture in Postwar Sweden, in ZWEDEN EN DE EUROPESE CULTUUR, 2001, ACTA VAN HET COLLOQUIUM GeOORGNISEERED IN SAMENWEKING MET DE KUNGLGLA VETENSKAPSAKADEMIEN (Royal Swedish Academy of Sciences) 37, 52 (M. Sohlman et al. eds., 1999). Professor Kjell A. Modeer of the University of Lund Law Faculty in Sweden believes that Sweden is being transformed from a national culture to a more international culture. See id. It is his position that lawyers more than judges are at the forefront of this transformation. See id. The Swedish legal profession is being "Americanized" as more law school graduates are seeking and finding positions in the private sector as Advokats so that they might better take advantage of the international opportunities presented. See id. One could argue that this phenomenon will empower the legal profession and energize it to become more active within its internal court system. See id.

10. See Introduction: Sweden, Basic Facts, at http://www.lysator.liu.se/nordic/scn/ faq71.html (last visited Jan. 25, 2003) [hereinafter Sweden Basic Facts]. California actually has a land mass of approximately 158,706 square miles. See Encyclopedia Britannica, available at http://www.Britannica.com/search?query=California\&ct=\&fuzzy=N (last visited Jan. 25, 2003).

11. See Sweden, Basic Facts, supra note 10. These figures are based on estimated census compilations as of 2000 when California had a population of $33,871,648$. However, that number has since been estimated at 34,501,130 as of 2001. See State and County QuickFacts, U.S. Census Bureau, available at http://quickfacts.census.gov/gfd/ states/06000.html (last visited Jan. 25, 2003); see also http://www.50states.com/californ.htm (last visited Jan. 25, 2003). 
of Sweden's land mass is covered by forest and is uninhabitable. ${ }^{12}$ Much of northern Sweden is on or above the Arctic Circle and sparsely populated while the south has farms and beaches and enjoys a rather mild climate and large population. ${ }^{13}$ Sweden is relatively homogeneous with approximately ten percent of the population born abroad. ${ }^{14}$ Although Sweden has recently experienced a growth in cultural diversity as a direct result of increased immigration trends and participation as an active member of the European Union, conformity and uniformity continue to be hallmark characteristics of the Swedish people. ${ }^{15}$

The general objective of this article is to provide a broad outline of the fundamental structure of the Swedish Legal System, to identify the current role of the legal profession in that system, and to make some general observations related to future development. The specific approach is: first; to present a broad overview of the Swedish System of Government, the Legal System and the Court System; second, to outline the Procedural Law that pervades the Swedish civil and criminal justice systems; third, to discuss the Swedish legal profession generally and its role within the legal system; and finally, to make suggestions for changes that might help the legal profession better prepare for a more active role in the legal system of the 21 st Century.

\section{SWEDISH SYSTEM OF GOVERNMENT}

Sweden's governmental structure is in many ways typical of other modern Western European representative Democracies. ${ }^{16}$

12. See Fredrik Sterzel, Public Administration, in SWEDISH LAW A SURVEY, supra note 1 , at 72,72 . Sweden's land mass is $50 \%$ greater than Italy's, which has seven times as many inhabitants and 30\% greater than Germany's, which has ten times as many inhabitants. See id.

13. See Sweden, Basic Facts, supra note 10. Approximately one-third of the entire population and most business and farming activity are concentrated in or near one of three southern urban areas: Stockholm metropolitan area $(1,686,000)$, Goteborg $(450,000)$, and Malmo (240,000). See id.

14. See Marianne Eliason, Citizens and Immigrants, in SWEDISH LAW A SURVEY, supra note 1, at 93, 98. According to one source, approximately 870,000 of the 8.5 million Swedish population was born abroad and only about fifty percent of that figure is not naturalized. See id. "Sweden has increasingly been transformed from a heterogeneous country with a substantial number of immigrants from several ethnic minorities . . . Since January 1, 1995, Sweden is also a member of the European Union. The monolithic culture has become pluralistic." Modeer, supra note 9, at 37. Prior to the advent of the European Union, the individual legal and political cultures of the Nordic Countries of Denmark, Finland, Norway and Sweden were loosely harmonized. See id. That local harmonization faded and an international harmonization emerged when Finland and Sweden joined Denmark as members of the Union in 1995. See id.

15. See Stig Stromholm, General Features of Swedish Law, in SWEDISH LAW IN THE NEW MILLENNIUM, supra note 2, at 31, 37.

16. See generally Par Cronhult, Introduction, in SWEDISH LAW A SURVEY, supra note 1, at 30-40. Presenting an historical perspective of the Swedish governmental structure. 
Sweden has a constitutional ${ }^{17}$ parliamentary democracy with a "weak" monarch as the representative head of state. ${ }^{18}$ Sweden has a long and colorful

17. For an English translation of the Swedish Constitution, see Sveriges Riksdag, The Swedish Parliament, at http://www.riksdagen.se/english/work/constitution.asp (last visited Jan. $25,2003)$ [hereinafter Riksdag]. Swedish constitutional history is rather complicated. Unlike that of the U.S., the Swedish Constitution has changed dramatically at various times over the years and, in fact, was completely reformed in 1974. See generally Fredrik Sterzel, The Constitution, in SWEDISH LAW A SURVEY, supra note 1, at 43, 44.

The Swedish Constitution actually consists of four separate Basic or Fundamental Laws, each of which has the status of a Constitutional Law. See id. at 43. The four basic laws are: "The Instrument of Government Act; the Act on Succession; the Freedom of the Press Act; and, the Freedom of Expression Act." Id. It is important to understand the distinction between Fundamental or Constitutional Acts and other levels of governmental laws. There are four levels of governmental laws in the Swedish system in the following hierarchy of importance: (1) Constitutional Acts; (2) Ordinary Acts enacted by Parliamentary vote; (3) Ordinances enacted by the Government; and (4) Statutory Instruments enacted by administrative agencies and local authorities. See Hans-Heinrich Vogel, Sources of Swedish Law, in SwEDISH LAw IN THE NEW MILLENNIUM, supra note 1 , at 48, 48. Constitutional Acts are considered first among all other acts or laws primarily because of the more complicated procedure that must be followed for them to be enacted. See id. For example, while Ordinary Acts require one affirmative vote of Parliament, Constitutional Acts must be voted favorably twice with a general election between the two Parliamentary votes. See id. The word "Constitution" when related to Sweden is used collectively herein and includes all four acts unless otherwise specified.

It should also be noted that Sweden is party to a substantial number of international agreements and conventions. See id. at 55. These are not considered as a part of the internal hierarchy of Swedish laws unless and until they are incorporated into national Swedish law. See $i d$. They become internal laws through a two-step process. First, they must be approved by the Swedish Parliament, and second, they must be added to Swedish law either by adding an explicit provision to an existing Act or Ordinance, including the new law, or by enacting the law as a new Act or Ordinance. See Hans-Heinrich Vogel, Sources of Swedish Law, in SWEDISH LAW IN THE NEW MillenNiUM, supra note 1, at 48, 48. This process is referred to as "transformation." See id. Once "transformed," these laws enjoy the same status as other Ordinary Acts of Parliament. See id.

Two very important international agreements that have been "transformed" into Swedish law are: The European Convention for the Protection of Human Rights and Fundamental Freedoms (European Convention) and the law of the European Union. See id.

The European Convention was not only transformed into Swedish law by an Act of Parliament (SFS 1994:1219), but it was added to the Swedish Constitution in the Instrument of Government (c. $2, \S 23)$ with the following proviso: "no law or other regulation may be promulgated which contravenes Sweden's undertakings under the Convention." Id. Thus, the European Convention has the equivalency of a Constitutional Act in the Swedish hierarchy of laws. See id.

The entire body of laws of the European Union were transformed into Swedish Law in a Parliamentary Act entitled Sweden's Accession to the European Union (1994:1500). See Hans-Heinrich Vogel, Sources of Swedish Law, in SWEDISH LAW IN THE NEW MILLENNIUM, supra note 1 , at 48,56 . In essence this Act transforms all treaties, acts, and other decisions of the European Union that occurred before Sweden's accession to the Union into law with binding prospective effect in Sweden. See id.

18. See Sterzel, supra note 17, at 43. The Instrument of Government Act of the Swedish Constitution sets forth the basic framework of the system of government. See id. at 46. Sweden's system of government is a prototypical Parliamentarian form. See id. at 52. The hierarchy of the power structure is Parliament, as the most prominent power responsible for enacting laws; Government (Prime Minister and Cabinet etc.), next most powerful with a mandate to rule the Realm as well as issue ordinances (regulations); and finally, Public 
political history that is beyond the scope of this article. However, some historical generalizations may be in order for a more complete perspective.

The basis of Sweden's modern governmental structure can be traced to the turn of the 18th Century when King Gustav IV Adolf, was forced to abdicate and leave the country. ${ }^{19}$ At that time, Parliament created a Constitutional Committee that produced a new Instrument of Government Act (Constitution). ${ }^{20}$ Although there was some thought that this Constitution would divide the powers more equally among the various branches, in reality, it had the opposite effect. ${ }^{21}$ The King and Royal Council were granted Executive power. ${ }^{22}$ Legislative power was placed jointly with the King, Council, and Parliament. ${ }^{23}$ A separate Judicial Branch and Ombudsman was created but delegated little power in relation to the other branches. ${ }^{24}$ The monarchy continued to be extremely powerful until sometime after World War II when, without any change to the Constitution itself, the King began to lose power to a stronger and more aggressive Parliament. ${ }^{25}$ Finally, in 1974, the Constitution was changed to reflect Parliament's assumption of a greater portion of power, a reality that had slowly insinuated itself into the governmental structure. This new Constitution specifically created a onechamber, more powerful Parliament which exists to this day. ${ }^{26}$

Authorities existing on both a national and local (Municipal) level with power to issue regulations. See id. As mentioned earlier, the Judiciary, while a part of the Swedish system, plays a less predominant role in the power structure. See id. The Instrument of Government also sets out the rights and responsibilities of the Monarch. See Sterzel, supra note 17, at 52.

19. See Cronhult, supra note 16 , at $32-33$.

20. See id. at 33-34. This Act had the status of a Fundamental or Constitutional Law. See id.

21. See id. at 34.

22. See id.

23. See id.

24. See Cronhult, supra note 16, at 34. The Ombudsman concept originated in Sweden introduced in an 1809 revision of the Instrument of Government. See id. In addition to providing a buffer between the citizens and the Swedish bureaucracy, the Ombudsman acted as a check on the power of the judiciary. See Modeer, supra note 9, at 47.

25. See Joakim Nergelius, Constitutional Law, in SWEDISH LAW IN THE NEW MILLENNIUM, supra note 1 , at 65,66 . It seems that during this period a variety of political changes occurred without regard to the language of the Constitution. See id.

26. See Cronhult, supra note 16 , at 37 . In effect, the Instrument of Government was changed, strengthening the power of Parliament such that even the Government, the branch that is responsible for the day-to-day operation of the country, became responsible to it. See id. This new structure is consistent with and emphasizes the importance placed on the principle that Parliament is the vehicle that best represents the will of the people. See id. The 1974 version of the Instrument of Government opens with the following section, "All public power in Sweden proceeds from the people. The people's rule of Sweden builds upon the free formation of opinions and a universal and equal suffrage and is reali[z]ed through a representative and parliamentary Constitution and a communal autonomy. All public power must be exercised under the law." Id.

Under the 1974 Constitution, Parliament is the most prominent power responsible for enacting Laws; Government (Prime Minister and Cabinet etc.) is next in power with a mandate to rule the Realm as well as issue ordinances (regulations); and finally, Public Authorities, 
Today, Sweden's King, Carl XVI Gustaf, although the titular head of state, serves only ceremonial functions. ${ }^{27}$ While the King does have a limited role in appointing a new government and selecting the chief executive, ${ }^{28}$ this chief executive nevertheless emerges from, and is totally dependant on and responsible to, the legislative or Parliamentary authority. ${ }^{29}$ Parliament thus assumes the most predominant role in the Swedish governmental structure. ${ }^{30}$

Parliament, the legislative arm of Swedish government, consists of a body of 349 freely and directly elected members who sit in a single chamber called the "Riksdag."31 Any member of the Government or Parliament can submit a proposal for enactment. ${ }^{32}$ The general rule is that only a majority of the Members of Parliament present and voting must vote in favor of a proposal in order for it to become a law. ${ }^{33}$ There are some exceptions specifically identified in the Constitution, however, when a qualified majority is required for enactment. ${ }^{34}$ The Prime Minister, who must be approved by vote of Parliament, is the leader of the Government. ${ }^{35}$ A new Prime Minister, when proposed by the Speaker of Parliament, will be approved unless a majority of the Members vote against him or her. ${ }^{36}$ The Prime Minister selects the other members of his or her government without the need for Parliamentary approval. ${ }^{37}$ However, with a majority of its Members voting in support, Parliament may at any time declare that either the Prime Minister or an individual minister of his or her government does not have their confidence. ${ }^{38}$

which exist on both a state and municipal level, have power in that they may also issue regulations. See Sterzel, supra note 17, at 52. As mentioned supra, the role of the judiciary is a much less important role under the terms of this document. See id.

27. See SwED. CONST. cl.1, $\$ 5$ (specifies that the King (or Queen) is the Head of State). The document, however, confers no powers on the Monarch except to provide that he or she "be kept informed on affairs of the Realm" and that, as necessary, he or she serve as Chair of the Government in Council. See Sterzel, supra note 17, at 46.

28. See SWED. CONST. cl. $1, \S 5$. Of course, as in any Parliamentary system, there are even limitations on this power in that the Monarch must select someone whom a majority of Parliament would then be willing to approve by vote. See Sterzel, supra note 17, a 47.

29. See Sterzel, supra note 17, at 44.

30. See id. at 46-61.

31. See Riksdag, supra note 17. Every Swedish citizen who is at least eighteen years of age is entitled to vote as long as they at one time resided in Sweden. See Sterzel, supra note 17, at 47. The Country of Sweden (Realm) is divided into twenty-eight regions or political constituencies. See id. Three hundred ten of the 349 Parliamentary seats are spread proportionately among the constituencies based upon voting population. See id. Given the demographics of the country as mentioned supra, the largest number of seats, and thus political power, is located in the southern part of the country. See id.

32. See Nergelius, supra note 25 , at 72 .

33. See id.

34. See id.

35. See id.

36. See id.

37. See id.

38. See Nergelius, supra note 25 , at 73. 
Such a vote would require the Government or the individual involved to resign. ${ }^{39}$

Since neither the Monarch nor the Court has the power to review acts of Parliament for conformity with laws of the Realm, including the Constitution, its power becomes absolute.

\section{SWEDISH LEGAL NORMS}

As mentioned previously, Sweden has a strong civil law tradition. For purposes of this article, that means, inter alia, Sweden's system of legal norms or laws consists primarily of legislative or parliamentary enactments reduced to writing and contained in a book entitled a "Code." Obviously, this is an overly simplistic explanation of a rather complicated and complex topic, but some perspective is in order.

The Swedish code was developed in $1734 .^{40}$ It consisted of all legal norms and customs that were in existence at that time. ${ }^{41}$ The norms themselves had evolved over a period of time in a variety of ways, including through principles developed and applied by a rather primitive judicial system. ${ }^{42}$ This system was comprised of judges that were basically educated in Continental European Universities teaching a system based upon influences generated by German-Roman law. ${ }^{43}$ Unlike the comprehensive Napoleonic Codes of 1804-1811, the 1734 Swedish Code was no more than a simple compilation of existing norms and customs. They were prepared with no pretense of reflecting a comprehensive legal structure permeated by a reasoned philosophical or enlightened approach to societal development. As Swedish legal and political culture developed, reflecting a cohesive and more enlightened pattern of thought, the Code became obsolete. ${ }^{44}$ It no longer met the needs of a changing society. ${ }^{45}$

There have been numerous unsuccessful attempts at re-codification over the years. For a variety of political and other reasons, a more philosophically reflective and complete Code remains elusive. Instead, the Swedish Parliament has continually added to and modified this original 1734 document in a piecemeal fashion. ${ }^{46}$ These changes reflect a variety of jurisprudential influences that have been in vogue over the years from sources of French and German origin as well as the social welfare philosophy of the internal Swedish

39. See id. at 72. The Prime Minister can avoid having his government replaced by calling a special election within one week of the vote of no confidence. See id.

40. See Cronhult, supra note 16 , at 37.

41. See id.

42. See id.

43. See id. Thus, aspects of the so-called Roman tradition found their way indirectly into the Swedish legal system.

44. See Modeer, supra note 9 , at 48.

45. See id.

46. See id. 
political power structure. ${ }^{47}$ Today the only part of the original 1734 Code that remains in existence is the cover and title page of the document. ${ }^{48}$

\section{SWEDISH LEGAL SYSTEM}

\section{A. General}

A strongly independent Parliament and existence of a comprehensive civil code place Sweden in line with most civil law systems. However, while there are certain characteristics and attributes that compare favorably, the Swedish legal system cannot be compared in all respects to other continental civil law systems. The Swedish system is unique in that while it has its roots in the Romano/German civil law tradition, it also has some influences from aspects of the common law tradition interspersed throughout. ${ }^{49}$

\section{B. Constitutional Review}

Sweden has had a Constitution of one type or another for almost as long as the United States. ${ }^{50}$ In fact, one of the four parts of the Swedish Constitution, the "Instrument of Government," dates from 1809..$^{51}$ Although the Constitution sets forth the political organization of the Swedish Realm, specifying its powers and establishing some procedural and substantive

47. See id. at 49.

48. See id. Interestingly, the Swedish civil code is less like a traditional comprehensive civil code such as exists in France and Germany and more like the kind of legislatively created interconnected but independent codes existing in the United States.

49. See Lindblom, supra note 3 , at 812 . The uniqueness referred to seems to be true for all Scandinavian countries in the area of private law. As Lindblom states, "Scandinavian private law constitutes a legal family of its own with five independent and sometimes cooperating siblings, with no forefathers or foremothers alive, and with some rather distant relatives on the continent." Id. Perhaps Sweden's form of civil law as a system of law is best described as follows:

The Nordic legal systems, though touched by the Roman law revival and affected in important ways by their proximity to the modern civil law systems, are generally thought of as sui generis, set apart by several unique features both from the common law and the mainstream of the civil law.

MARY ANN GlENDON ET AL., COMPARATIVE LEGAL. TRADITIONS 60 (1984).

50. See Sterzel, supra note 17, at 43.

51. See Cronhult, supra note 16, at 33. It is also interesting to note that Sweden lays claim to the first "Freedom of the Press Act," which has existed as a Fundamental Law in Sweden since 1766. See id. Professor Modeer maintains that the 1809 Instrument of Government was strongly influenced by Montesquieu's theory of Separation of Powers. See Modeer, supra note 9, at 47. This philosophy resulted in an Act subordinating the role of the king and elevating that of the judiciary within the Swedish political structure. See id. During the period roughly up to the outbreak of World War I, the judiciary enjoyed a time of independence and power. See id. In fact, in the Instrument of Government of 1809, Parliament delegated power of "judicial preview" to the Swedish High Court obliging the government to submit all bills of reform to the Court for constitutional pre-review before they could be considered by Parliament. See id. 
limitations on the exercise of those powers, it has in the past played a much less influential role than other Ordinary Acts of Parliament on the everyday life of Her citizens and in the general development of Swedish law..$^{52}$ This is true in spite of the fact, as mentioned above, that constitutional acts by the nature of their mode of enactment are considered first in the hierarchy of importance among laws in Sweden. ${ }^{53}$ It is only recently that the Swedish Constitution has truly become a part of the legal system, recognized by government, courts and the people in general as "a living element of social life." 54 One familiar with the American political model realizes that constitutionalism and federalism are the centerpieces, and judicial review is considered the norm. The United States Constitution stands as a bulwark against legislative and executive infringement of the fundamental rule of law. ${ }^{55}$ Constitutionalism, as developed in the United States, demands a vehicle free of political power and influence to assure the permanency and superiority of the document and its basic human rights protections. ${ }^{56}$ Of course, early on it was the Supreme Court in this country that assumed the power of constitutional interpretation. ${ }^{57}$ Today, when appropriately raised, it is the duty of any court in the American legal system to make a decision as to the

52. See Nergelius, supra note 25 , at 68 . The Instrument of Government is a rather complete document setting forth not only the framework of the branches of government but also limited provisions relating to Human Rights protections for Her citizens. See id. On the question of Human Rights, it should be noted that Sweden has also accepted as Swedish Law the European Convention for the Protection of Human Rights and Fundamental Freedoms. See id. Similar to the U.S. Constitutional protections, the protections afforded human rights in Sweden extend to governmental infringements but not to those occurring at the hand of private parties. See id.

53. See Stromholm, supra note 15 , at 37. "[C]onstitutional acts and ordinary acts stand out as the most important legal sources because of their very special role as instruments to express the people's will during the struggle for democracy and parliamentarism in the 19th and early 20th centuries." Vogel, supra note 17, at 48.

54. Sterzel, supra note 17 , at 61 .

Constitutional questions rarely appeared in the Swedish courts but are not unusual nowadays. Constitutional viewpoint has become a natural part of both the legal and the political basis for argument. Constitutional law, which just 20 years ago was almost considered to be a historical curiosity in the study of law is now gaining terrain as a complete part of the positive law.

Id.

55. See Mauro Cappelletti, The "Mighty Problem" of Judicial Review and The Contribution Of Comparative Analysis, 53 S. CAL. L. REV. 409, 430 (1980).

56. See id.

57. See Marbury y. Madison, 1 Cranch 137 (1803). In 1803, United States Supreme Court Chief Justice John Marshall enunciated the doctrine of judicial review as follows:

It is emphatically the province and duty of the judicial department to say what

the law is. Those who apply the rule to particular cases, must of necessity expound and interpret that rule. .. A law repugnant to the Constitution is void;

... courts as well as other departments are bound by that instrument.

Id. Interestingly, between the Marbury case and the case of Dred Scott v. Sandford, 19 Howard 393 (1897), no other federal law or portion of it was declared unconstitutional by the Supreme Court. See ABRAHAM, supra note 6, at 346. 
Constitution's applicability to a situation. No court in Sweden has this power. ${ }^{58}$ However, since the 1970 s subtle changes have occurred allowing Swedish courts to take a more active role in the interpretation and application of the Constitution to the lawmaking process. ${ }^{59}$

In 1980 , Parliament passed legislation specifically conferring a very limited power of judicial review upon courts in Sweden authorizing them to set aside Parliamentary Acts that might conflict with the Constitution or some other higher authority ${ }^{60}$ It seems this power of judicial review, such that it is, is available at all levels of courts, administrative and general, and to public authorities as well. ${ }^{61}$ However, the judicial review that is authorized in this provision is less than complete. For example, constitutional decisions of the Supreme Court, or other higher courts, have no binding effect on lower courts. $^{62}$ Further, while judicial review of an Act of Parliament or other government ordinance is authorized, it is nevertheless limited to only those instances where the law in question is "manifestly" incompatible with the Constitution or some other superior provision of law. ${ }^{63}$ Finally, as mentioned

58. See Vogel, supra note 17 , at 58 . Of course, the awesomely broad power of judicial review established by Chief Justice Marshall in Marbury and its progeny will not be found in any other system to the extent it exists in the United States. See id. As mentioned previously, while historically the Supreme Court in Sweden has not had a role in directly reviewing legislation vis-a-vis the Constitution, there is, nevertheless, a system in place that is designed to accomplish a similar purpose in Sweden. See generally Sterzel, supra note 17, at 43 . From 1809 to 1909 this power of constitutional pre-review was delegated to the Swedish High Court. See id. at 44 . Since 1909 , no legislation can be finally promulgated until it undergoes a rather extensive pre-enactment approval process by a group called the Council on Legislation. See id. This body is composed of justices of both the Supreme (General) Court and the Supreme Administrative Court. See id. The main purpose of this review of all legislative proposals is to consider the way in which the legislation "relates to the fundamental laws and the legal system in general and what problems are likely to arise in applying the law." Vogel, supra note 15 , at 58. If this body finds major problems with the proposal and renders a negative opinion, the proposal does not usually become enacted by the Riksdag. See id.

59. See Sterzel, supra note 17, at 45. Following World War II, many civil law countries have moved toward a more active constitutional control over legislative and executive power. In many cases the courts have been taking on the responsibility. In others, the view is that judicial review is anti-democratic. The theory is that it is more appropriate for decision of conformity with the constitution to be made by the elected majority in the legislature rather than the less democratically selected judiciary.

60. See id. at 59. See also Nergelius, supra note 25 , at 78.

61. See Sterzel, supra note 17 , at 59.

62. See Ulla Jacobsson, General Procedural Law, in SWEDISH LAW A SURVEY, supra note 1 , at 489,489 . It does seem that the court decisions play a major role in establishing precedent for practitioners as they prepare their cases or advise clients especially on procedural matters that have no statutory basis. See id.

63. See Sterzel, supra note 17, at 60 . In 1980, c.11, $\$ 14$ of the Instrument of Government was changed as follows:

If a court or other public authority finds that a provision conflicts with a provision of the fundamental laws or other enactment of higher dignity or that a legislative provision has in important respects been disregarded when it was made, the provision may not be applied. If the Parliament or the Government 
above, the judicial review power specified in the Instrument of Government (Chapter 11, Article 14) is not solely within the province of the courts but also extends to public authorities. ${ }^{64}$ All of these factors seem to have the effect of minimizing and diluting the overall effect of the review power. ${ }^{65}$

In addition, Sweden has created a Council on Legislation to serve as an alternative method to use of courts for legislative oversight. ${ }^{66}$ Theoretically, this entity is authorized, when requested by the Parliament or Government, to review legislative proposals, inter alia, for their conformity with the Constitution. ${ }^{67}$ It is not mandatory to request review and the opinion of the Council is not officially binding. ${ }^{68}$ Nevertheless, it seems when the Council actually is asked and renders an opinion on a matter it is given appropriate deference. ${ }^{69}$

\section{Courts}

Swedish courts have not played a particularly active role in the interpretation of legislation vis-a-vis the Constitution over the years. Nevertheless, they have been available as a method for resolving disputes between private parties and, of course, as the primary vehicle in the criminal justice system. $^{70}$

have decided the provision, its application must however only be avoided if the error is manifest.

Id.

64. See id.

65. See Nergelius, supra note 25 ; at 79.

66. See id. at 80. It has been suggested that there are two general models for judicial review; one is the American model and one is referred to as the Austrian model. See J.A. Jolowicz, Summary of the 1984 Scientific Colloquium of the International Association of Legal Science on "Judicial Review and its Legitimacy," in COMPARATIVE LEGAL TRADITIONS, supra note 49, at 75. Under the Austrian model, questions of the constitutionality of legislation are decided by a separate special constitutional court. See id. The procedure for bringing the question to the constitutional court will vary depending upon the model followed. See id. For example, in 1958 France enacted a system of constitutional review of Parliamentary Acts by creating a governmental entity called Conseil Constitutionnel (Constitutional Court). See Marcel Waline, The Constitutional Council of the French Republic, AM. J. COMP.L. 483 (1963). The court was empowered to review the constitutionality of laws only upon the request of the executive and only before they were promulgated. See id.

67. See Nergelius, supra note 25 , at 80.

68. See Louis Favoreu, The Constitutional Council and Parliament in France," From Constitutional Review and Legislation: An International Comparison, in COMPARATIVELEGAL TRADITIONS, supra note 49 , at 80.

69. See Nergelius, supra note 25 , at 80.

70. See Lindblom, supra note 2, at 239 . However, use of courts to resolve civil disputes in Sweden is the exception rather than the rule and cannot be compared to the use of courts in the United States. See id. 
The general structure and power of the courts in Sweden is found in Chapter 11 of the Instrument of Government. ${ }^{71}$ This Instrument states that "the Supreme Court is the highest court of general jurisdiction and the Supreme Administrative Court is the highest administrative court."72

Included in the Instrument of Government is a provision specifying that no authority, including Parliament, may determine how a court should adjudicate a particular matter. ${ }^{73}$ This provision prohibits outside powers from imposing any influence on how a court (administrative or general) decides a case. The Constitution also requires legislative enactments to establish fundamental procedures for the operation of the courts. ${ }^{74}$ While it has not always been the case, a fair reading of these relatively recent Constitutional provisions would support a conclusion that Parliament intends the Judiciary to be independent and free from outside influences in its decision-making, thus assuming a more proactive role in the legal system. ${ }^{75}$

A more detailed description of the Swedish Court System including, inter alia, organization, procedures, and other related matters is contained in the Swedish Code of Judicial Procedure. ${ }^{76}$

Courts and administrative authorities share responsibility in the Swedish legal system for enforcing the legal rules as developed by Parliament. Sweden is similar to other civil law countries in that there is a demarcation of jurisdiction between courts and these administrative authorities. ${ }^{77}$ This distribution of power is set forth generally in the Swedish Constitution (Instrument of Government) and more specifically in subsequent legislation. ${ }^{78}$

71. See Rune Lavin, Administrative Law and Procedure, in SWEDISH LAW IN THE NEW MILLENNIUM, supra note 1, at 89,90. Courts are divided into two categories, Administrative and General. See id. In addition to these two general categories of courts, there are some highly specialized courts in Sweden. See id. For example, beginning with the enactment of an Environmental Code in 1998, a system of environmental courts was established, including a Supreme Environmental Court. See id. These specialized courts serve the exclusive function of dealing with appeals from decisions of administrative authorities in environmental cases. See id. Other examples of specialized courts include the Labour Court, Maritime Courts, Real Property Courts, and Water Rights Courts. See Jacobsson, supra note 62, at 496.

72. Nergelius, supra note 25 , at 78 .

73. See Sterzel, supra note 17 , at 59.

74. See id.

75. See id. Other provisions in the Instrument of Government relating to the judiciary include provisions establishing the tenure of judges and legal review of closed cases. Id.

76. The Swedish Code of Judicial Procedure (SCJP) was promulgated in 1942 and first published in English as Volume fifteen in the American Series of Foreign Penal Codes. SCJP citations in this article refer to the most recent English translation published by the Swedish Ministry of Justice, Regeringskansliet - Justitiedepartmentet (Norstedts Tryckerie AB, Stockholm 1998) [hereinafter SCJP].

77. See Sterzel, supra note 12, at 77. The Instrument of Government provides that "for the administration of justice there are courts of law and for the public administration there are state and municipal administrative authorities." Id.

78. See generally Hugo Tiberg, Introduction to Private Law, in SWEDISHLAW A SURVEY, supra note 1 , at 117,118 . Typically a civil law system divides disputes into either a private or public law category. See id. Generally, private law governs matters that would be considered 
This division of power is particularly important and necessary in a country like Sweden, which fashions itself as a democratic state governed by law, including a substantial public welfare and social service structure in place for its people. ${ }^{79}$ In essence, either Parliament enacts laws or the Government issues instructions that affect the various administrative authorities and agencies. ${ }^{80}$ These, in turn, promulgate regulations on matters within their purview. ${ }^{81}$ As would be expected, a large administrative bureaucracy is necessary to manage a system such as this in a socialistic style country like Sweden. ${ }^{82}$ There are three different levels of local government administration in Sweden: central, regional, and local/municipal. ${ }^{83}$ Administrative agencies and authorities exist at each of these levels. In order to assure Her citizens of effective protection in this administrative hierarchy, an elaborate specialized administrative court structure was established to handle public law disputes. ${ }^{84}$ These administrative courts are separate from the general court structure that is designed to accommodate matters of a criminal and private law nature. ${ }^{85}$

Following is a brief overview of the organization of the two primary court systems in the Swedish judicial structure, the administrative and the general courts. ${ }^{86}$

civil law in the United States and would be initiated between private parties, e.g. property, tort, contract etc., as well as criminal law. These matters are within the jurisdiction of the general courts. See id. Public law refers to those matters where an administrative decision making authority is a party and would include e.g. welfare and tax matters among many issues. See id. These matters would be within the Administrative Court's jurisdiction. See id.

79. See Sterzel, supra note 12, at 72. Sweden has an extensive "cradle to grave" social welfare structure that is uniquely Swedish/Scandinavian. See Xan Smiley, The Five Nordic Countries Remain Defiantly Different from the Rest of Europe . . . and from Each Other, THE ECONOMIST, Jan. 23, 1999, at 3. The Swedish legal historian, Kjell A. Modeer, characterizes the political period from 1976 to present as the Party-related Period. See Modeer, supra note 9, at 41 . He maintains that the political culture can be divided into two factions, one more nationally oriented and the other more internationally oriented. See id. The nationally oriented faction maintains the more traditional social welfare principles and is comprised of the Socialdemocratic, Left (Communist), Green and Center (Farmer) parties. See id. The internationally oriented faction leans toward the European Union and maintains a philosophy supportive of separation of powers with a strong court system including power of judicial review. See id. This faction is represented in the Conservative, Christian Democrat and Liberal parties. See id.

80. See Sterzel, supra note 12, at 73.

81. See id.

82. See id.

83. See id. The information contained herein is at best a simplistic explanation of the Swedish Public Law System. For an excellent in depth discussion in English see id.

84. See id.

85. See Sterzel, supra note 12 , at 73. Public Administrative Authorities are not considered an official part of the $S$ wedish Government although they can only receive directives from the Government. See id. at 74. In addition, general courts have no jurisdiction or power of review over decisions made by Public Authorities. See id.

86. See Lindblom, supra note 2, at 207. Administrative responsibility for all of Sweden's courts is centralized within the purview of the National Court Administration headed by a Director-General. See id. 


\section{Administrative Court System}

Administrative law in Sweden has both a procedural and a substantive aspect. $^{87}$ For example, a sophisticated set of formal procedural rules for administrative matters has been developed to assure an equitable system for citizens to deal with issues arising in the public law context. ${ }^{88}$ The centerpiece of administrative procedure is the administrative court system. Substantive administrative law is extremely broad and includes, inter alia, matters relating to environmental law, social services, ecclesiastical law, social welfare, regulation of business activity, and the general exercise of public power designed to facilitate the functioning of society. ${ }^{89}$

Specific examples of the range of administrative law issues that would affect the lives of most Swedish citizens include: regulation of a driver's license, licenses to operate nuclear power plants, taxes and social insurance benefits, to name a few. ${ }^{90}$ The typical situation arising in the Administrative Court would be an appeal by a private individual against an adverse decision of an administrative authority in one of the above areas of interest. ${ }^{91}$

There are three levels of administrative courts. ${ }^{92}$ The first level administrative court is the County Administrative Court. ${ }^{93}$ There are twentyfour administrative judicial districts each with a County Administrative Court. ${ }^{94}$ Jurisdiction of these courts extends not only to appeals from decisions of local or regional authorities but also to certain cases heard as an original matter. ${ }^{95}$

87. See Lavin, supra note 71 , at 89.

88. Administrative procedure is primarily contained in two laws, the Administrative Procedure Act, 1986:223, and the Administrative Courts Procedure Act, 1971:291.

89. See Lavin, supra note 71 , at 89-90.

90. See id. at 89. Not all areas of administrative law are within the jurisdiction of the administrative courts. As mentioned above, some areas of administrative law are considered broad enough and important enough to justify their own special courts. Examples include environmental law and marketing law. See id. at 90.

91. See id. at 99. An individual who has had an adverse decision from an administrative authority brings most administrative cases in the county administrative court. See id. However, it is also possible for an administrative authority itself to file an application directly in the county administrative court. See id. Examples would include cases involving care and custody of children or adult drug abusers, psychiatric care, administrative fines, repayment of disbursed social benefits, etc. See Lavin, supra note 71, at 99.

92. See Sterzel, supra note 12 , at 75.

93. See Lena Marcusson, Administrative Procedure, in SWEDISH LAW A SURVEY, supra note 1 , at $545,547$.

94. See id.

95. See id. Examples of cases heard in the first instance include: cases involving involuntary commitment for drug and alcohol abuse, and cases relating to child abuse or neglect that could result in removal of the child. See id. Examples of appeal from a local or regional administrative authority include: Tax assessments, social welfare decisions, social security insurance matters. See id. 
The second level of administrative courts consists of four Administrative Courts of Appeal in Stockholm, Goteborg, Sundsvall, and Jonkoping. ${ }^{96}$ These courts hear appeals not only from decisions of the county administrative courts but also directly from decisions of various administrative authorities. ${ }^{97}$

The highest level of administrative court is the Supreme Administrative Court. ${ }^{98}$ This court sits in Stockholm and is comprised of nineteen justices and has the power to not only review decisions of the Administrative Courts of Appeal but also to review cases directly from regional or central administrative authorities. ${ }^{99}$ The opinions of this court are published and thus in principal, only those cases which impact most broadly are accepted for review.

While it is beyond the scope of this work to review or even to completely describe all the characteristics of the Swedish system of administrative procedure, the following are some generalizations about administrative procedure that deserve mention, albeit superficially. ${ }^{100}$ Proceedings in the administrative courts can be conducted either entirely through written submissions or in certain cases via oral presentation. ${ }^{101}$ The education and training of administrative judges is the same as that of general court judges. ${ }^{102}$

Certain administrative cases that have the characteristics of a criminal case will often be treated procedurally in the same fashion as regular criminal cases. ${ }^{103}$ For example, if an administrative matter is considered criminal in nature, special voting rules to establish liability and proof beyond a reasonable doubt will be required. ${ }^{104}$ In addition, in cases of this nature, the administrative court itself will be composed of a legally trained judge and three lay judges. ${ }^{105}$ Administrative Courts of Appeal have three legally trained members but usually no lay judges. ${ }^{106}$

96. See id. See also Jacobsson, supra note 62, at 497.

97. See Marcusson, supra note 93, at 547.

98. See Sterzel, supra note 12, at 75.

99. See Jacobsson, supra note 62, at 498; Marcusson, supra note 93, at 548 .

100. For a very good discussion see SWEDISH LAW A SURVEY, supra note 1, at 545-66.

101. See Lavin, supra note 71, at 106. The trend seems to be to allow oral presentations more often in the administrative courts. See id. Previously, writing was the only method of proceeding. See id. Writing is still an important part of administrative proceedings with written submissions allowed after the oral hearing on the matter. See id.

102. See Marcusson, supra note 93, at 547.

103. See Lavin, supra note 71 , at 107 . Typically these cases may result in some penalty if established e.g. revocation of licenses (driver's or professional) and disciplinary measures against health care professionals or others. See id.

104. See id.

105. See Riksdag, supra note 17. Lay assessors or judges are appointed for a term of six years by municipal councils and sit as a panel in general district and appeals courts (not administrative courts) on criminal, family and in some instances land law matters. See Lindblom, supra note 2, at 208. They are considered part-time and sit for one or more days per month. See id. The lay judge's vote has the same weight as the vote of a professional judge. See id.

106. See Jacobsson, supra note 62 , at 497. 
A party to an administrative matter is entitled to have legal counsel provided via the extensive Swedish Legal Aid System in the same manner that a person with a private legal matter would be so entitled. ${ }^{107}$

An administrative court has the same range of discretionary power in fashioning a remedy for an individual as the original governmental decisionmaking authority would have in the first instance. ${ }^{108}$ Administrative courts have a broad spectrum of jurisdiction that includes hearing cases on appeal from previous adverse decisions of an administrative authority as well as entertaining administrative cases of first impression. ${ }^{109}$ Not all adverse decisions of the county administrative courts are subject to appeal to the Administrative Courts of Appeal. Leave to appeal to the Supreme Administrative Court is granted in only about two to three percent of the cases where it is requested. ${ }^{110}$

\section{The General Courts}

There are three levels of general courts in Sweden: district courts (tingsratter), courts of appeal (hovratter), and the Supreme Court (Hogsta domstolen). ${ }^{111}$ As mentioned above, the general courts are the courts most closely analogous in jurisdiction to American civil and criminal courts. They deal with both criminal and civil cases and generally have jurisdiction over all cases that have not been explicitly excepted from their jurisdiction. ${ }^{112}$

107. See Lindblom, supra note 2, at 231. See infra Part IV.D3 for a more complete discussion of public legal aid in Sweden.

108. See Marcusson, supra note 93 , at 546.

109. See id. at 547. In fact, there are some instances when an administrative authority's decision can not be reviewed by either an administrative or a general court. See id. at 546 . However, in those cases when court review of an administrative decision is not available there may be an alternative option to seek review from a superior administrative authority. See id.

110. See Lavin, supra note 71 , at 105.

111. See Lindblom, supra note 2, at 203.

112. See id. Included among the excepted, in addition to administrative court matters, are certain specific substantive topics such as labor, environmental etc. See id. As mentioned previously, special courts have been created to deal with these areas of law and thus they are outside the purview of the general courts. General courts in Sweden may not review decisions of administrative authorities or administrative courts. See Marcusson, supra note 93, at 546. Interjurisdictional issues can be particularly troublesome in civil law systems with a separate administrative court structure as well as a general court structure. See GLENDON ET AL., supra note 49 , at 118 . Generally in many civil law systems special procedures are established to resolve these questions of jurisdiction between the two courts. See id. For example, France has a special Tribunal of Conflicts to decide whether a case belongs in the administrative or general court jurisdiction. See id. at 119. Germany has a system whereby each court has power to decide if it will take jurisdiction or transfer the case to the other court's jurisdiction. See id. Sweden's system is more like Germany than France. Many of the jurisdictional issues are resolved legislatively with a few remaining issues centering on the extent to which a general court could review administrative decisions. See Lavin, supra note 71 , at 96 . Recently the Swedish Supreme General Court has limited the jurisdictional power of the general courts to review only private law issues and leave the public law issues to the administrative courts. See 
There are approximately ninety-six district courts spread throughout Sweden. ${ }^{113}$ These are the courts of first instance and the most active in the Swedish legal system. In civil cases, .a three judge quorum hears more complex cases, while small claims and less complicated matters are heard by a single judge. ${ }^{114}$ Family law and criminal cases are usually heard by one professional judge and three lay judges. ${ }^{115}$ Except for cases involving freedom of the press, there are no juries in the Swedish legal system. ${ }^{116}$ However, although not completely analogous, the use of lay judges presents a rather interesting altemative to the American petite jury.

Lay judges sit in panels along-side professional judges in both the district courts and the courts of appeal on matters of criminal, family, and to some extent land law cases. ${ }^{117}$ They have the power to decide not only issues of fact but also questions of law. ${ }^{118}$ Their decisions on matters of law carry the same weight as professional judges in the case. Lay judges are nominated by the local (municipal) political parties, then they are selected and appointed by the government for a four-year term. ${ }^{119}$ Lay judges must reside in the district where they sit, and they cannot be affiliated with the legal profession as either a judge, advokat, prosecutor, or practicing lawyer. ${ }^{120}$

id. Thus, general courts will not enjoin or order specific performance against administrative authorities. See id. Further, general courts will not take jurisdiction of a case which requires special administrative law knowledge leaving such decisions to administrative authorities. See id.

113. See Lindblom, supra note 2 , at 203. The size and makeup of these courts vary depending upon the population served. See id. For example, Stockholm, the largest city in Sweden, has more than one hundred permanent judges sitting in its district court. See id.

114. Unless the case is uncomplicated or the parties consent, there is a requirement for three professional judges to constitute a quorum. See id. at 204; SCJP, supra note 76, at c.1, §a.

115. See Lindblom, supra note 2 , at 208.

116. See id.

117. See Ulla Jacobsson, Criminal Procedure, in SWEDISH LAW A SURVEY, supra note 1, at 499,500. The number of required judges, lay and professional, in the district and court of appeals depends upon the penalty that attaches to the crime charged. See id. at 501. Generally speaking, one professional judge and three lay judges is sufficient in the district court. See SCJP, supra note 76 , at $c .1, \S 3 \mathrm{~b}$. In more serious criminal cases there can be as many as five lay judges and in the less serious there may not be any lay judges. See Jacobsson, supra note 118 , at 501 .

In the courts of appeal for most cases three professional judges constitutes a quorum. See SCJP, supra note 76, at c. $2, \S 4$. Cases that are in the court of appeal on appeal from the district court will have "at least four legally qualified judges... if the district court consisted of three legally qualified judges." $I d$. at c. $2, \S 4$. In the less serious criminal cases there are usually three professional judges and no lay judges. See Jacobsson, supra note 118, at 501. In more serious criminal cases three professional judges and two lay judges constitute a quorum. See id.

118. See SCJP, supra note 76 , at c. 30

119. See id. at c. $4, \S 8$.

120. See id. at c. $4, \S 6$. 
As of 1999, there are six general courts of appeal spread throughout the various regions of Sweden. ${ }^{121}$ Technically, any district court decision is subject to appeal to the court of appeal, however, such appeals are very rare. ${ }^{122}$ An appeal is in reality a trial de novo as all issues of fact and law are subject to reconsideration by the court of appeal. The composition of the appeals court will vary depending upon the composition of the district court that initially heard the case. ${ }^{123}$

The highest court in the Swedish general court system is the Supreme Court sitting in Stockholm. ${ }^{124}$ As of December 1999, it was comprised of sixteen professionally trained justices sitting in two divisions. ${ }^{125}$ Three justices sit as a panel on all matters that are considered of a minor nature whereas five justices are necessary to decide more serious issues. ${ }^{126}$ The Supreme Court has evolved to the point where it has become a precedent setting court and will only take cases that are considered to be of importance throughout the Realm. ${ }^{127}$ When the Supreme Court does take a case, it sits in much the same manner as a district court and a court of appeal, deciding all issues of fact and law. ${ }^{28}$

\section{Overview of Procedural Law in Sweden}

There are two very important documents necessary to the proper functioning of the Swedish legal system: the Swedish Code of Judicial Procedure (SCJP) ${ }^{129}$ and the Enforcement Code (EC). ${ }^{130}$ Rules of criminal procedure and civil procedure are contained in the SCJP. The EC contains a rather extensive set of rules and procedures relating to the creation and

121. See id. at c. $2, \S 6$. The two appellate courts in Stockholm and Jonkoping, respectively, trace their beginnings to the seventeenth century. See Jacobsson, supra note 62 , at 497. In addition, there are courts of appeal in Malmo, Umea, Sundsvall, Goteborg. See id.

122. See Lindblom, supra note 2, at 204. Approximately eight percent of civil cases and ten percent of criminal cases are appealed to one of the six appeals courts. See id.

123. See id. Where the district court case was heard by a professional judge along with lay judges, the appeals court will be composed of three professional judges and two lay judges. See id. In cases where there were no lay judges involved in the district court case, the appeals court will be comprised of three professional judges. See id. If there were three professional judges sitting on the case in the district court, the appeals court will have four professional judges sitting as a quorum. See id.

124. See Jacobsson, supra note 62, at 497.

125. See SCJP, supra note 76, at c.3, § 4. At least two members of the Council on Legislation are included within this number of justices. See Jacobsson, supra note 62, at 497.

126. See SCJP, supra note 76 , at c. $3, \S \S 5,6$.

127. See Lindblom, supra note 2 , at 229.

128. See id.

129. "The Swedish Code of Judicial Procedure was first promulgated in 1942 and came into force on January 1, 1948" SCJP, supra note 76, preface. The most recent English translation of the SCJP was published in 1998 by the authority of the Swedish Ministry of Justice. (Norstedts Tryckeri AB, Stockholm 1998).

130. See Jacobsson, supra note 62, at 488. 
administration of a system of enforcement mechanisms for the decisions of all the courts, governmental authorities, and arbitration panels. ${ }^{131}$

\section{Enforcement Procedures}

Traditionally, in civil law systems the courts have no contempt power. ${ }^{132}$ In the absence of contempt power, in order for the court's judgment and decision to be meaningful there must be some other mechanism available to assure enforcement. ${ }^{133}$ In Sweden, there are distinct organizations, known as Enforcement Authorities, responsible for court decisions as well as, when necessary, decisions of governmental authorities and arbitration panels. ${ }^{134}$ The Enforcement Code sets forth the contours establishing and defining the Enforcement Authorities. ${ }^{135}$ Generally, each of the twenty-four counties in Sweden has one Enforcement Authority (Authority). ${ }^{136}$ The individual Enforcement Authorities are under the direct control of the National Tax Authority, which is responsible for managing, directing and supervising them. ${ }^{137}$ An Enforcement Authority is comprised of officers who are trained in either law or economics and who sit as quasi judicial officials. ${ }^{138}$ The Enforcement Authority is authorized to conduct mini hearings known as summary proceedings to determine if the matter presented is ripe for enforcement and meets legal standards. ${ }^{139}$ An application is filed with the Enforcement Authority by a claimant requesting relief as awarded through judicial decision. ${ }^{140}$ The Enforcement Authority notifies the defendant of the claim and requests a responsive answer. ${ }^{141}$ In matters of enforcement of court decisions, the power of the Enforcement Authority does not extend to a reexamination of the case. ${ }^{142}$ However, it is within the power of the Enforcement Authority to consider matters such as, "objection by the debtor that he already satisfied the judgment, that he has a set-off claim or that his unsettled matters with the creditor is a hindrance for the enforcement."143

131. For a thorough discussion see Ulla Jacobsson, Enforcement, in SWEDISH LAW A SURVEY, supra note 1, at 556-65.

132. See GLENDON ET AL., supra note 49 , at 167.

133. See id. In the French system, under a process referred to as astreinte, the court has the power to impose financial sanctions to add weight to its judgments. See Beardsley, Compelling Contract Performance in France, 1 HASTINGS INT'L \& COMP. L. REV. 93 (1977).

134. See Jacobsson, supra note 131, at 556. The types of enforcement that might be requested include execution on real property, personal property, debtor's claims, attachment of wages, eviction of a tenant, specific performance of a contract. See id. at 559.

135. See id. at 556-57.

136. See id. at 556.

137. See id.

138. See id. at 557.

139. See Lindblom, supra note 2 , at 220.

140. See id.

141. See id.

142. See Jacobsson, supra note 131 , at 557 .

143. See id. 
Subsequently these same officers are responsible for the actual enforcement activities undertaken by the Authority to satisfy the judgment which usually involves some form of attachment or collection. ${ }^{144}$

\section{Code of Judicial Procedure}

The system of procedural rules in Sweden is rather complicated and to some extent different from many other civil law systems. In civil law cultures, rules of civil procedure tend to maintain a level of importance equivalent to the position afforded to American substantive civil law. ${ }^{145}$ Rules of civil procedure govern every aspect of the operation of the legal system, both criminal and civil, and extend from the role of the courts, the bar, and the prosecutors to the actual court proceedings themselves. ${ }^{146}$

\section{Legal Aid}

\section{i. Civil}

There is a rather extensive public legal aid system in place in Sweden. ${ }^{147}$ In general terms, the premise behind this system is that every citizen is entitled to legal assistance regardless of his or her ability to pay. Legal aid will be granted in some proportion to anyone and everyone who has a need for legal services and no private legal insurance to pay for it. ${ }^{148}$ Technically there is a maximum income limit in order to qualify for public legal aid, but this limit is relatively high by Swedish standards and thus includes a large part of the population. ${ }^{149}$ For those who qualify, the amount of public legal aid actually awarded will vary in proportion to the party's financial status. ${ }^{150}$ It should be

144. See id. at 557-58.

145. See GLENDON ET AL., supra note 49, at 166.

146. See Lindblom, supra note 2 , at 201.

147. See id. at 231-32; "[T] here are five forms of legal aid paid by the State: general legal aid in civil cases, legal advice, public defense counsel, counsel for the aggrieved person and public counsel." Id. at 231.

148. See id. Legal insurance is rather common in European civil law systems as a means of assuring that legal needs of those of moderate means are met. See generally, M. CaPPElletti eT Al., TOWARD EQUal Justice: A Comparative STUdy of Legal Aid in MODERN SOCIETIES, 178 n. 3 (1975).

One estimate is that over ninety-five percent of the Swedish population is covered by private legal insurance through either their home or car policy. See Lindblom, supra note 2, at 231. If a person is capable of having private legal insurance and chooses otherwise they will not be afforded public legal aid. See id.

149. See Lindblom, supra note 2 , at 232 . This source lists the income limit at 260,000 SEK (approximately $\$ 26,000 \mathrm{US}$ ) which incorporates approximately ninety percent of the Swedish population. See id.

150. See id. The variation may be between two and forty percent of costs. See id. 
pointed out, however, public legal aid does not cover the losing party's obligation to pay the prevailing party's legal costs. ${ }^{15 !}$

Through a combination of public legal aid and private legal insurance, it seems that no citizen in Sweden is denied access to legal assistance due to an inability to pay.

\section{ii. Criminal}

In serious criminal cases an accused is entitled to have public defense counsel appointed by the court in addition to compensation for the costs of preparing a defense. ${ }^{152}$ Counsel may be appointed at any stage of the proceeding, including the preliminary investigation stage, before the inquiry has progressed to the initiation of formal charges. ${ }^{153}$ While the suspect can request the appointment of a particular legal counsel, it is ultimately the court's decision and in any event the legal aid appointment must be of an Advokat. ${ }^{154}$

\section{E. Civil Proceedings Under the Swedish Code Of Judicial Procedure $(S C J P)$}

The plaintiff begins the civil judicial process in Sweden by filing a written summons application in the district court. ${ }^{155}$ This summons must state the plaintiff's claim with facts in support including proposed written evidence. ${ }^{156}$ The district court reviews the summons and, if it finds it is based on valid legal ground, will issue a summons to the defendant and order preliminary proceedings to commence. ${ }^{157}$ Preparatory proceedings are conducted by a single judge whose function at this stage is to have the parties

151. See id. A party's private legal insurance does fulfill this obligation, however, most private legal insurance coverage is limited to approximately 100,000 SEK. See id.

152. See SCJP, supra note 76, at c.21. Preparation costs may include expenses incurred in relation to the following matters, "production of evidence, travelling expenses and subsistence." Lindblom, supra note 2, at 232. Public defense counsel will always be appointed when a person is suspected of committing a serious crime, is detained, or is placed under arrest. See id. at 233.

153. See Lindblom, supra note 2, at 233.

154. See id. In 1999, an Advokat was compensated at the rate of 1,000 SEK (approximately $\$ 100$ US) per hour. See id.

155. See id. at 214. The SCJP also contains provisions for small claims cases. See id. at 217. These provisions were developed to provide a quick, less expensive alternative to the regular civil trial for those civil cases where the financial claims are more modest. See id. In 1999 , the amount, which is adjusted annually to meet inflation figures, was limited to SEK 16,000 (approximately $\$ 2,000$ US). See Lindblom, supra note 2, at 217. The small claims cases are held in the same district courts as other civil cases but different less formal rules apply. See id. at 217-19.

156. See id. at 214. Plaintiff must append any documentary evidence that is important to her claim. See id.

157. See id. The defendant is required to answer the summons in writing. See id. 
lay out the details of their case including a recitation of the evidence upon which they intend to rely. ${ }^{158}$

In theory, under the principle of orality the case must eventually proceed to a courtroom hearing in order for a court decision to be rendered. ${ }^{159}$ In certain cases this hearing can take place in simplified form without the formalities associated with a main hearing. ${ }^{160}$ The judge may adjudicate the case alone based upon the material presented at the preparatory pre-trial proceeding without the need of a subsequent formal courtroom hearing. If the case continues to the formal hearing stage, the rules of orality, immediateness, and concentration apply and the judgment must be based only upon what is presented orally to the judge or panel of judges at the hearing. ${ }^{161}$ These three principles applicable to the Swedish system distinguish it from most other civil law systems where the rule is more often that there is no single trial but rather a continuous series of "meetings, hearings, and written communications during which evidence is introduced, testimony is taken, and motions are made and decided."162

The actual procedure during a civil trial in Sweden is similar in many ways to an adversarial civil trial in the American legal system. ${ }^{163}$ As

158. See Lindblom, supra note 2, at 214. Unlike the American system, there is no party initiated discovery in a civil case. See id. at 215. In addition, there is a movement in Sweden to encourage judges to be more directly and actively involved in the preliminary phase of the case. See id. The objective is to eliminate any incompleteness and clarify the position of the parties prior to the oral hearing and to encourage settlement where appropriate. See id.

159. See id. The three main principles of the judicial trial system in Sweden are: orality, immediateness, and concentration. See id. at 215-16. In summary, this means that if a case progresses to trial the court's decision must occur immediately following an uninterrupted hearing where oral evidence is presented. See Lindblom, supra note 2, at 215-16. Although the general principle is that the case cannot be decided without a trial, the judge does have some options to resolve the case at the pretrial phase of the proceedings. See id. at 216.

[T] he court may (1) dispose of the case otherwise than by judgment, (2) enter a default judgment, (3) enter a judgment based upon a party's consent to, or concession of, a claim, (4) confirm a settlement and (5) enter a judgment ... if neither a main hearing is needed in view of the inquiry into the case nor any of Id. the parties request a main hearing.

160. See id. The principle of immediateness generally requires that to be effective a judgment must be based solely upon what has been presented at a main hearing. See id. at 212 . However, an exception to the principle exits in cases where the hearing occurs before the judge who has been conducting the preparatory proceedings and is familiar with all the evidence and either renders a decision in conjunction with the pre-trial conference or within fourteen days thereof. See id.

161. See Lindblom, supra note 2, at 212. There are provisions in the SCJP for the court to call recesses and adjournments in the case; however, under the principle of concentration, the case must proceed generally uninterrupted until all evidence is presented and a decision can be made. See id. at 216.

162. GLENDON ET AL., supra note 49, at 166.

163. See id. Of those cases where a summons is requested in the Swedish system, only a small number actually proceed to a main hearing or trial. See id. In a way, this is very similar to civil cases in the United States that also tend to settle before trial in large numbers. One 
mentioned previously, there are no juries in civil cases in Sweden, but there is a panel of three legally trained professional judges. Each party has an opportunity to make an opening speeches, present oral evidence, and make a closing address to these judges. ${ }^{164}$ There are no rules of evidence and each witness, including the parties, although subject to questioning by counsel, as well as the judges, is encouraged to give their testimony unobstructed by objections. ${ }^{165}$ Parties need not be represented by legal counsel but if they so desire to be represented they may choose any lay person, legally trained or not, or a legally trained individual who might or might not be a qualified Advokat of the Swedish Bar Association. ${ }^{166}$ Finally, in Sweden the losing party pays the litigation expenses of the prevailing party as determined by the court. ${ }^{167}$

\section{F. Criminal Proceedings Under the SCJP}

The Swedish criminal justice system has a tripartite organizational structure each interconnected but independent from the other. ${ }^{168}$ Included, in

Swedish commentator has stated: "To-day the majority of civil cases are decided during the preparation and do not proceed to a main hearing." Ulla Jacobsson, Civil Procedure, in SWEDISH LAW A SURVEY, supra note 1, at 515, 523.

164. See Lindblom, supra note 2 , at 216.

165. See id. The examination of witnesses is almost exclusively conducted by counsel in the Swedish system with the judge taking part, more or less, as she believes necessary. See id. This process is more akin to the adversarial American model than it is to the typical civil law, more inquisitorial model. A more typical civil law example might be in the nature of that required under German civil procedure. See GLENDON ET AL, supra note 49, at 170 . In the German system, the judge is the prime interrogator of the witnesses asking them, among other things, their name, age, and occupation. See id. Then, inviting them to give their testimony uninterrupted. See id. Upon completion, legal counsel for the parties might be invited to ask questions of the witness, but rarely is the invitation accepted. See id.

166. See Lindblom, supra note 2 , at 216 . A party can practice law without being an Advokat, a special designation for a person legally trained who is also a member of the Swedish Bar Association. See infra Part V.

167. See id. Included in the expenses of litigation are costs for counsel, costs associated with the party's own work on the case, party's loss of time and costs associated with the production of evidence. See id. at 216-17. There are provisions for situations where the determination of prevailing party is not clear. See Jacobsson, supra note 163, at 521. If necessary, under the SCJP

costs can be divided four different ways...: 1 full reimbursement: if one of the parties has substantially won the case, 2 apportionment: the party who has won the most receives a percentage reimbursement related to the percentage he has won, 3 "set-off": each of the parties is responsible for his own costs... 4 special division: one party pays the opposing party's costs in the part of the case he has lost.

Id.

168. See Jacobsson, supra note 117 , at 499 . Of course, the Bar also plays a predominant role in the system as defense counsel. See id. at 498 . Another independent organization which has a substantial impact on the criminal justice system is the National Prisons and Probation Administration which is responsible for dealing with people convicted of crime, including the issues surrounding parole decisions. See id. at 499-00. 
addition to the courts, are the Police Authority and the Prosecution Authority. ${ }^{169}$

The Police Authority consists of a National Police Board headed by a National Police Commissioner with supervisory authority over approximately 100 local police districts and twenty county districts. ${ }^{170}$ Of course, the primary responsibility of the police is to investigate crimes and work with the prosecutor in developing evidence. There is a National Police College for the training of police officers located in Stockholm. ${ }^{171}$ Police service consists of two different career paths, uniformed police officer or criminal investigator. ${ }^{172}$ Hierarchically the Prosecution Authority consists of a National ProsecutorGeneral with supervisory responsibility over district, county, and regional prosecutorial offices. ${ }^{173}$ The prosecutor in the Swedish criminal justice system has a variety of tasks similar to those of her American counterpart including: heading the police investigation, deciding on when to prosecute a given case, and representing the State's interest in the prosecution of a case. ${ }^{174}$

Similar to the American and English criminal justice systems and unlike other civil law systems, the Swedish system treats the investigatory stage of criminal proceedings as inquisitorial but the trial stage as more adversarial. ${ }^{175}$ However, the Swedish criminal trial process is not completely analogous to an

169. See id. at 499.

170. See id. at 499-00.

171. See National Council for Crime Prevention, Sweden, World Factbook of Criminal Justice Systems: Sweden, available at http://www.ojp.usdoj.gov/bjs/pub/ascii/wfbcjswe.txt (last visited Jan. 25, 2003) [hereinafter National Council for Crime Prevention].

172. See id. Qualifications necessary to train as a uniformed police officer recruit are "Swedish citizenship, a high school education, a minimum of one year work experience outside the police, good health and a suitable body for police work, a driver's license, the ability to swim," and at least twenty years of age at the time of application. Id. The training program for a uniformed police officer spans a three year period including an initial ten months at the police college, eighteen months at one of the 117 police districts, and a final period of five months back at the police college before being placed in the field at a district office. See id.

In order to become a criminal investigator it is necessary to have a university degree in law. See id. In 1991, there were 700 applicants to train for the position of criminal investigator and thirty were accepted. See id. In addition to a law degree, training to become a criminal investigator requires three years of study at the National Police College with emphasis on analysis and planning, administration and workplace psychology. See National Council for Crime Prevention, supra note 172. In addition, it requires field work throughout the criminal justice system including placement with the police, courts, and prosecutor's offices. See id.

173. See Jacobsson, supra note 117 , at 500 .

174. See id. It seems that whenever possible the same prosecutor will be involved in the case from beginning to end, including, with permission of the Prosecutor-General, presenting the case before the Supreme Court.

175. See id. at 503. For an excellent beginning to end discussion of a criminal proceeding in a typical civil law system see Rudolf B. Schlesinger, Comparative Law reprinted in GLENDON ET AL., supra note 49, at 180. A common misconception among Americans is that the civil law system treats the suspect as "presumed guilty until proved innocent." GLENDON ET AL., supra note 49, at 179 . This is certainly not the case in the Swedish system where there are a number of safeguards in place to protect the suspect at each stage of the criminal process. 
adversarial model as the court/judge plays a much more active and direct role in the case in Swedish criminal proceedings. ${ }^{176}$ For example, at the trial stage, a judge will often actively question witnesses and may even request parties to submit additional evidence. ${ }^{177}$

The Swedish criminal justice process is divided into four stages: the preliminary investigation, the prosecution, the main hearing, and decisionmaking. ${ }^{178}$

There is no Grand Jury or counterpart in the Swedish system. A prosecutor who has sufficient evidence to conclude that a suspect is guilty of a crime begins the trial process by filing with the court a written application for a summons. ${ }^{179}$ Following is a somewhat superficial outline of the various steps in the criminal justice process. Of necessity it is of a general nature and has substantial subtleties that require further exposition and development beyond the scope of this article.

\section{The Preliminary Investigation And Prosecution Stages ${ }^{180}$}

176. See Jacobsson, supra note 117, at 503 . In many civil law systems the court takes an active role along with the prosecutor at an early stage of the investigation. See id. This is not the case in Sweden where except for unusual situations where the freedom of the suspect is at issue the court is not usually actively involved until the trial itself begins. See id.

177. See id.

178. See id. at 504.

179. See id. at 509 . The prosecutor must be very detailed and specific in this application as it provides the framework for the trial. See Jacobsson, supra note 117, at 509. It must describe the charged offense with specificity including the time, place, and manner of commission with a description of each item of evidence he will use in establishing the case. See id. Subsequently a court will not sentence a defendant for an offense not described in the summons. See id. A court may allow a prosecutor to expand the definition during the trial under certain circumstances. See id.

180. See id. As mentioned above, the early stages of the preliminary investigation are conducted outside the scope of the court's supervision, initially by the police and, later, including the prosecutor. See id. The court does have a limited role during the preliminary phase on matters such as placing a suspect in custody. See Jacobsson, supra note 117, at 509. The Swedish criminal justice system is replete with instances at every stage to protect the accused and help to insure that innocent people are not convicted of a crime. See id. The concept most often used to describe these protections is favor defensionis. See id. at 504. The protections are articulated in terms of probabilities in the Code of Judicial Procedure and applied at each phase of the process. See id.

1. when someone may be suspected of a crime ... he is obliged to remain at the police for questioning for 12 hours, CJP ch $23 \sec 9$,

2. when someone can be reasonably suspected of a crime ... the prosecutor shall take over the investigation, and the suspect shall be informed, CJP ch $23 \sec 3$ and $\sec 18$,

3. when someone on probable grounds is suspected of a crime ... he can be committed into custody by the court, subject to certain further conditions, CJP ch $24, \sec 1$,

4. when there are sufficient grounds to believe that the suspect is guilty of the crime ... the prosecutor shall prosecute, CJP ch $23 \sec 2$ and ch $20 \sec 9$.

Id. (emphasis added). 
When there is reason to suspect that a crime has been committed the police will begin an investigation. ${ }^{181}$ In some cases the prosecutor may be involved in an advisory capacity with the police at these very early stages of the investigation. ${ }^{182}$ However, more often the prosecutor will not be involved until the police investigation extends beyond the issue of whether a crime has been committed and is more focused on an individual suspect. When a decision is made that there is a person who can be reasonably suspected of a crime, the prosecution takes over and the police work to develop evidence in support of the prosecutor's case. ${ }^{183}$

In Sweden, every citizen is required to appear at the request of the police for questioning in connection with the investigation of a crime. ${ }^{184}$ At the point during the investigation when it becomes clear that a person is reasonably suspected of committing the crime, he is informed of his right to public defense counsel. ${ }^{185}$ Certain coercive measures may be used against a suspect and his property including apprehension, arrest, prohibition of travel, requirement of reporting to police, physical examination, bodily search, photographing and fingerprinting and ultimately holding in custody. ${ }^{186}$ However, physically placing a suspect in custody is a decision that is not made lightly and requires an order of the court. ${ }^{187}$

After making the decision to prosecute, the summons is requested and the prosecutor prepares for the main hearing. ${ }^{188} \mathrm{~A}$ written report is filed with

181. See id. at 505. Of course, in many instances, the suspect may be arrested during or shortly after the commission of a crime. See Jacobsson, supra note 117 , at 505 . In these cases the police will begin the investigation with an interrogation of the suspect and the collection of potential evidence. See id.

182. See id.

183. See id.

184. See id. The police have the ability to detain a person for questioning up to six hours without the need of any special approval. See id.

185. See SCJP, supra note 76 , at c.23, $\S 5$. Defense counsel and the suspect are kept informed during the police investigation of the evidence developed and are encouraged to provide information to assist as the case progresses. See id.

186. See id. at c.24-28. These sections specify the coercive measures and their requirements in detail.

187. See id. at c. $24, \S \S 1-3$; see also Jacobsson, supra note 117 , at 506 . In order to have a suspect placed in custody it is necessary for the prosecution to file an application with the court. See id. A hearing is required immediately or in any event by the day following the application. See id. There are two situations where the court may commit a suspect into custody. See id. First, if there are probable grounds to believe the suspect has committed a crime the penalty for which is imprisonment for one year or more he may be held in custody if one of the following special grounds exist: "1. risk of escape, 2. risk of tampering with evidence, 3. risk of continuation of criminal activities." Id. Second, if the minimum penalty for the crime is two years or more in prison the court should order custody unless it is evident that none of the grounds listed above exists. See id. When the court issues a custody order it simultaneously issues a time limit for the initiation of prosecution. See Jacobsson, supra note 117, at 507. New hearings for renewal of the custody order must be held at a minimum of two week intervals until prosecution is commenced. See id.

188. See Lindblom, supra note 2 , at 224. 
the court by the prosecutor containing a full description of what has transpired at the preliminary investigation, including a list of evidence and names of witnesses she expects to present at trial. ${ }^{189}$ There is no plea-bargaining in the Swedish system and, thus, there must be a main hearing in every case when a decision is made to proceed with charges. ${ }^{190}$

\section{The Main Hearing}

Similar to a number of civil law systems, the Swedish trial court has no lay jury but, instead has a mixed panel of professional judges and lay judges. ${ }^{191}$ This mixture of judges acts as a single body, simultaneously deciding issues of both law and fact as well as guilt and punishment. ${ }^{192}$ Any judgment made must be based on evidence presented to the court on the day of the trial. ${ }^{193}$ Similar to Anglo-American adversarial trials, both defense and prosecution in Sweden follow a standard fixed trial progression including opening speeches, presentation of evidence, and closing addresses. ${ }^{194}$ In addition to the prosecutor and defense counsel, the injured party in the matter may also be present, with or without counsel, and is entitled to testify, examine witnesses, and present evidence for the court to consider. ${ }^{195}$ Neither the defendant nor the

189. See id. The court has the power to summons witnesses of its own to the main hearing regardless of the desires of the parties. See id.

190. See Jacobsson, supra note 117 , at 505 . This procedure should be contrasted with other civil law systems where the prosecutor makes a preliminary decision whether to proceed to the formal charging stage of the process. See id. For example, in France, if the decision is made to proceed the prosecutor prepares a very extensive dossier of relevant evidence including witnesses to be called by defense and prosecution. See GLENDON ET AL., supra note 49, at 182. This dossier is then presented to a panel of judges for a second decision as to whether the evidence is strong enough to proceed to a trial. See id. The panel has broad authority, usually inviting defense counsel to present argument on the issue of whether there is "reasonable cause" to proceed to a formal trial. See id.

191. See SCJP, supra note 76 , at c. $1, \S 3 \mathrm{~b}$. The bench in the Swedish district court for criminal cases consists of one professional judge and three to five lay judges, depending upon the nature of the charge. See id.

192. See Lindblom, supra note 2, at 224.

193. See id.

194. See id.

195. See id. A person who has in some fashion been harmed by the criminal conduct of the accused and who has a private claim for damages sustained may have his or her claim consolidated, with the prosecutor's assent, as part of the prosecution's case against the defendant. See SCJP, supra note 76, at c.22. In the trial, witnesses are not restricted by rules of evidence in their testimony. See Jacobsson, supra note 117, at 509. The tendency is to encourage the witnesses to present their evidence uninterrupted and in a free flowing, unrestricted manner. See id. at 510. Questions can be asked of witnesses by the judges and counsel as well as the injured party. See id. 
injured party testify under oath at the trial..$^{196}$ No other witnesses are allowed in the courtroom while the defendant and the injured party testify. ${ }^{197}$

After presenting evidence of guilt or innocence, the parties will immediately present evidence relating to the punishment to be imposed upon conviction and make closing arguments on both issues. ${ }^{198}$

\section{Decision Making Phase}

Although the Swedish Code of Judicial Procedure is silent on the point, the Swedish Supreme Court has decreed that the prosecution must prove every element of the crime charged beyond a reasonable doubt. ${ }^{199}$ Also, as mentioned previously, the principle of free evaluation of the evidence applies in both civil and criminal hearings in the Swedish system. ${ }^{200}$ In essence, this requires the court to accept and carefully review all the evidence presented in the case without regard to issues of admissibility.

Judges are required to deliberate and vote on a case immediately upon its conclusion. ${ }^{201}$ The lay judges usually do not vote until after the professional judge or judges have voted. The ultimate judgment must be in writing and signed by the professional judge or judges who participated in the decision. ${ }^{202}$

\section{Appeal of Criminal Cases}

In the Swedish criminal system both the defendant and the prosecutor have the ability to appeal an adverse decision to the Court of Appeals. ${ }^{203}$ The

196. See Lindblom, supra note 2 , at 225 . Interestingly the reason for this is that the risk of perjury is too substantial with the parties that have the most interest in the case. Eliminating the fear of a perjury conviction may encourage a defendant or injured party to testify more readily. Of course, the obvious negative implication here is that interested parties always lie to protect their interests.

197. See id.

198. See id. This evidence is usually presented in writing and consists of matters relating to the personal circumstances, including previous convictions, of the defendant. See id.

199. See Jacobsson, supra note 117 , at 512 .

200. See id. at 494 . The theory behind this principle evolves from the reality that while there are no lay juries in the Swedish system, except for Freedom of the Press cases, lay judges are utilized extensively in criminal cases. Lay judges, who are appointed for a term of four years, are more sophisticated than a transient petty jury and, thus, it is more appropriate for them to be allowed along with the professional judges to decide what factual information is fruitful in deciding the issues.

201. See id.

202. See id. at 513.

203. See id. at 511. See also SCJP, supra note 76, at c.49. This is typical in most civil law systems. See GLENDON ET AL., supra note 49, at 190 . There are minor exceptions to this general rule in Sweden. For example, "review dispensation" must be obtained if the prosecutor or defendant wishes to appeal a case where the sanction imposed was merely pecuniary. See SCJP, supra note 76 , at c. $49, \$ 13$. In addition, review dispensation is required if a prosecutor wishes to appeal a case where the defendant was acquitted of a crime which has a maximum penalty of six months imprisonment. See id. 
case on appeal may proceed either with or without a new main hearing (de novo) or without one based upon which is most advantageous to the defendant. ${ }^{204}$ If the case proceeds on appeal with a new main hearing, the parties may present new or additional evidence to the Court of Appeal.

It is very rare for the Swedish Supreme Court to accept an appeal of a case with little precedential value. ${ }^{205}$ In order for a convicted defendant to appeal his case to this Court, he must seek review dispensation, which is rarely granted except in cases where the defendant establishes extraordinary reasons such as new evidence. ${ }^{206}$ In those few cases that are accepted on appeal, the Supreme Court will decide issues of both fact and law. ${ }^{207}$ Although it is not required, it is possible for the Supreme Court to hold a new main hearing on appeal with the presentation of evidence including testimony of witnesses. ${ }^{208}$

\section{THE LEGAL PROFESSION}

In America, and most common law systems, the legal career path upon completion of legal training is rather direct. ${ }^{209}$ Upon passing the bar examination in most jurisdictions in America, the law graduate becomes a "lawyer," at least theoretically, licensed to represent clients in any legal context within the state where licensed. Very few irrevocable career choices must be made by a young law student during law school or immediately

204. See Jacobsson, supra note 117 , at 511 . There are special rules that apply to the appeal of cases which have been decided favorably to the defendant in the district court. See id. In essence these rules require the appeals court to hold a new main hearing when the prosecution is appealing from a favorable district court decision for the defendant. See SCJP, supra note 76 , at c.51, \&23.

205. See Lindblom, supra note 2, at 229. The Prosecutor-General may appeal a criminal case to the Supreme Court of Appeal without the need to obtain review dispensation. See id.

206. See SCJP, supra note 76 , at c. $54, \S 10$, c.58, $§ 2$. See also Jacobsson, supra note 117 , at 512 . "Extraordinary reasons" may be found to exist if there are substantive defects in the court of appeal proceeding, if grave procedural errors have occurred, or a gross oversight or mistake exists as a basis for the court of appeal decision. See Lindblom, supra note 2, at 229.

207. See Lindblom, supra note 2 , at 229.

208. See id.

209. Although each state sets its own bar admission standards, most require that applicants graduate from an accredited law school and possess "good moral character." An interesting study was published in 1982 which divided the American legal profession into two groups based generally upon the type of client that the lawyer chose to represent. One group consisted of those lawyers who choose to represent individual clients and, the other, those who chose corporate or institutional clients. HeINZ AND LaUman, CHICAGO LAWYERS: THE SOCIAL STRUCTURE OF THE BAR (1982). Of course, there are some common law systems where the young law student must make choices early in their legal training. England, for example, requires students early in their legal education to choose whether they wish to work directly with clients in the more transactional office setting as a Solicitor or be a litigator specially trained to represent the client in court as a Barrister. See GLENDON ET AL., supra note 49, at 553. Once made the choice is difficult if not impossible to reverse. See id. 
thereafter. ${ }^{210}$ The career choices that are available after law school and throughout one's professional career generally center on whether to work in a large or small firm, solo practice, or in-house with a corporation or a governmental agency. ${ }^{211}$ At some point later in one's legal career it is possible for a small number of the profession who have enjoyed distinguished careers to either be appointed or elected to the judiciary. ${ }^{212}$

By contrast, in Sweden, a young law school graduate does not have a specific bar examination or equivalent to confront, has no character standards imposed, and generally has not only the same choices as his or her American counterpart, but also some additional choices that must be made very early in their career. ${ }^{213}$ Among these choices are whether to become a judge, a criminal investigator or police officer, a prosecutor, or an Advokat.

\section{A. Legal Education}

In many ways, the legal profession in Sweden is a much more accessible profession than it is in the United States or England. Certainly in England and, to a large extent, in America, the legal profession tends to be a closed, selfregulated, tradition-laden, hierarchical community. This is not true in Sweden. Sweden does not have a formal licensing program as such for those who wish

210. Of course, students will be encouraged to experience different aspects of the legal profession to the extent they can while still in law school. In addition, many students will come to law school with preconceived ideas of specific areas of interest which may or may not change as they make their way through legal study. Students will take courses in areas of interest and even, in many instances, participate in live client clinical experiences and obtain part time employment in their areas of interest prior to graduation. The point is, however, that no hard, fast career choices must be made while still a student. In America we pride ourselves on the fact that after completion of a general legal education and passage of the bar examination, our options are unlimited and continue to be available throughout our careers.

211. American lawyers tend to think of law as a multidimensional profession presenting a variety of career avenues with options to switch from one to another at any time. One may practice law for four or five years and then move to the judiciary, government, or teaching for instance. In civil law systems it is necessary to choose one's legal career path very early in training. A decision to enter the judiciary begins upon completion of legal education with selection to serve as a law clerk and progression to appointment as a sitting judge. There is very little lateral mobility in the legal profession in civil law systems after the initial career decision.

212. Lawyers in America are seldom prepared for the role of a judge other than through the years they have spent as practicing members of the bar. There is no formal training process for those lawyers aspiring to the judiciary and it certainly is not considered a career choice open to every member of the profession.

213. See generally Legal Studies in Uppsala, at http://www.jur.uu.se/legal.htm (last visited Jan. 25, 2003) [hereinafter Legal Studies]. Indeed, many career choices must be made while still a law student in Sweden, and they tend to be irrevocable. Of course, academic standing plays as much of a significant role in Sweden as it does in the United States in this regard. For example, only about the top five to ten percent of the class will be accepted into the entry level for training as a judge. 
to hold themselves out as representatives of the public in legal matters. ${ }^{214}$ In fact, regardless of formal training in law, any citizen can represent themselves or any other citizen in any legal matter whether transactional or adversarial and whether civil or criminal. ${ }^{215}$ Regardless of this, however, a large number of young people enter university law programs every year. ${ }^{216}$

All education in Sweden is "free" and, at least theoretically, any person who meets the academic standing requirements will be admitted to the law faculty of their choice and may pursue any career path in law upon completion. $^{217}$

It is difficult to obtain statistics as to the exact number of students being trained in the law in Sweden at this time. However, there is information available from which to make some educated guesses. There are five major universities in Sweden, each with a law faculty and a law curriculum. ${ }^{218}$ Student enrollments in the law curriculum tend to be very high in all five universities. One example is the University of Lund, located in southern

214. See generally The Swedish Bar Association, available at http://www. advokatsamfundet.se/english/index_eng.htm (last visited Jan. 25, 2003) [hereinafter Swedish Bar Association].

215. There are some limitations that will be discussed below. For example, in order to be appointed by a court to represent someone charged with a crime, one must be an Advokat. However, if a citizen is not interested in legal aid they can choose any person they wish to represent them.

216. See generally Legal Studies, supra note 214.

217. See Susanne Billum, Social Welfare, in SWEDISH LAW A SURVEY, supra note 1, at 106, 109, citing Student Support Act (1973:349). Not only is university education tuition-free, but students are awarded other financial support via state allowance and low interest loans while they are students. See id. In fact, "study support" in the form of allowance and loans is available to students at the high school level. See id. This "study support" is partly a grant available to any student, regardless of income level. See id. University admissions standards reflect a major difference between obtaining a legal education in a civil law country such as Sweden and a common law country such as the United States. See John Henry Merryman, Legal Education There and Here: A Comparison, 27 STAN. L. REv. 859, 861 (1975). Civil law countries tend to be more "democratic" in nature, automatically opening their doors to anyone who has completed the formal prerequisites. See id. Contrast this with the more meritocracybased method applied in most law schools in the United States, where undergraduate grades, and sometimes school, and score on the nationally standardized Law School Aptitude Test are the predominant determinants for admission to law school. See id.

218. See Legal Studies, supra note 213. The Swedes do not use the term law school to identify that part of the university that teaches a law curriculum. See id. More properly a student is enrolled in a law faculty and, even more precisely, it is referred to as "Juridicum." See id. As is true in most civil law countries, there are no private law schools apart from the State university system in Sweden as there are in the United States and elsewhere. See id. In addition, even though there may be a separate building containing classrooms and offices for the law faculty and students on a university campus, it is an integral part of the university itself. See id. As mentioned above, the more precise way to identify that part of the university that teaches law is "Law Faculty." See id. In order for clarity and to establish a familiar frame of reference, however, "law school" will be used throughout this article in place of law faculty. See Legal Studies, supra note 213. The five major universities in Sweden are: Uppsala, Lund, Stockholm, Göteborg, and Umeå. See id. 
Sweden outside the large industrial seaport city of Malmö. ${ }^{219}$ The University of Lund has a total enrollment of approximately 2500 students in its law curriculum. ${ }^{220}$ Somewhere in the vicinity of 350 students complete the program at Lund and enter the workforce each year. ${ }^{221}$ Professor Kjell-Åke Modeer of the University of Lund Law Faculty has suggested that approximately 1500 students graduate from all law schools in Sweden each year. ${ }^{222}$ While a small number of these graduates will continue their careers as legal scholars in academia, most will go on to other endeavors such as the judiciary, police, prosecutors, private practitioners, civil service and perhaps a small number to become advokats and of course, many will enter into careers in the business community. ${ }^{223}$ As mentioned above, all these choices are available and most must be made immediately upon completion of legal education.

Law training in Sweden, similar to most civil law countries, consists of an undergraduate university education. As a generalized contrast with its common law counterpart, European legal education tends to be more theoretical than vocational. ${ }^{224}$ Although this remains true in Sweden, there appears to be some movement away from the pure academic model among some Swedish Universities. ${ }^{225}$ Certain programs, for example the University of Lund, are beginning to experiment with more practical-oriented courses emphasizing professional skills development. ${ }^{226}$ Regardless of the modest

219. See Lund University, available at http://web1.jur.lu.se (last visited Jan. 25, 2003). 220. See id.

221. See Kjell A. Modeer, From Samuel Pufendorf To The Raoul Wallenberg Institute: Lund University Law School During Three Centuries, 25 INT'L J. LEGAL INFO. 5, 16 (1997).

222. See id.

223. See id.

224. See Modeer, supra note 9 , at 45

225. See id. "The law schools are in an interesting period of change. Their curricula are changing from having emphasized public law to private law, from national norms to international, from theory to more practice-oriented classes." Id. Not surprisingly, legal education in civil law systems is generally designed to comport with the requirements of the profession in those countries where the lawyer/judge is more of a technician engaged in mostly uncreative and routine work in a system that has existed for many years and demands no more of its participants. Quite a contrast from the theoretical model of the American lawyer who is trained as a problem-solving jack-of-all-trades equally adept at resolving specific problems of individuals and those of a broader societal nature. See Merryman, supra note 217, at 867. Professor Modeer maintains that Swedish legal culture is changing from an idealistic to a pragmatic model. See Modeer, supra note 9 , at 52 . Where lawyers previously saw themselves mostly as technicians, or more flatteringly, social-engineers loyal to the state, they have now become "Americanized." See id. According to Professor Modeer, a "neo-liberal economy and weakening state economy" have moved the profession away from public sector careers into more lucrative and challenging private-sector careers. See id. These changes will, of course, require adjustments in the philosophy and approach to legal education.

226. See Modeer, From Samuel, supra note 221, at 15. There are many reasons one might surmise for this gradual change in philosophy. Professor Modeer suggests a few in his article. See id. Since the late $1950 \mathrm{~s}$ Sweden has made an effort to expose its population to opportunities for training in other European languages. See id. at 14. In particular, students were offered opportunities to study English in early childhood education classes. See id. As a result, today 
modern trend, Swedish legal education generally remains true to the legal science ideology of nineteenth-century European legal training. ${ }^{227}$

As mentioned previously, five universities in Sweden have law faculties and offer complete programs of study in law. ${ }^{228}$ Each university has its own curriculum but there is little overall variation among the universities. ${ }^{229}$ All the specific information in this article comes from the law program at the University of Lund Law Faculty. ${ }^{230}$

There are no tuition fees in the Swedish universities. Lund accepts approximately 300 students each year. ${ }^{231}$ Requirements for admission are completion of upper secondary school in Sweden or its equivalent elsewhere,

much of the population in the country over age forty speaks excellent English. See id. This generation went on to universities and studied law. See id. Many traveled to the United States and obtained advanced law degrees from U.S. law schools and returned as young faculty members to their Swedish law faculties. See Modeer, From Samuel, supra note 221, at 14. Subsequently, as faculty members, they took advantage of opportunities to spend sabbatical time at U.S. law schools where they were exposed to the combination of theory and practice that most U.S. law schools employ. See id. Combined with this, the European Community concept was developing and the career opportunities for Swedish students were changing with greater possibilities in the international arena and throughout the European Community. See id. The need to rethink the philosophy and objectives of legal education was presented and, slowly, some changes are being implemented today. See id. at 14-16.

227. See id. at 16. Following is a description of the objectives of the University of Lund Law Program as contained in its 1999-2000 Academic Bulletin:

Legal education shall provide the knowledge and skill required for work with questions concerning the legal system and the application of law. It shall give a good overview of the legal system and, of such, theoretical knowledge and skill as are required for professions for which the degree of Master of Laws is a qualification and shall provide an understanding of the legal system in an international perspective.

1999/2000 Lund Bulletin, at 15.

228. See Legal Studies, supra note 213.

229. See id. A comparison of the curricula at the University of Lund Law Faculty and Uppsala University Law Faculty shows the similarities of curricula. See id. Each program consists of a mandatory course-level and an optional course-level with a degree thesis required. See id. While the names of the courses in the two programs may vary somewhat upon review, it is clear that the content is similar. An example of the similarity can be seen by reviewing the first-year curriculum of both programs that require students to take courses in Constitutional Law, Introduction to Swedish Law, and Basic Civil (Private) Law. See id. Curriculum uniformity is no less in United States law schools. Certainly a review of first-year programs at most United States law schools would reveal a core of required courses in Contracts, Property, Civil Procedure, and Criminal Law, among others.

230. See Modeer, From Samuel, supra note 221, at 6-7. The law faculty at the University of Lund is known as "Juridicum." See id. This is one of the oldest law faculties in Sweden, established as part of the University of Lund's original charter in 1666. See id. As of 2000, the University of Lund has a population of slightly more than 37,000 students with approximately 1500 in the law curriculum. See id. Among the first law professors at Lund was Samuel Pufendorf, considered the Patriarch of International Law and Jurisprudence. See 1999/2000 Lund Information Bulletin; Lund University, supra note 219.

231. See Lund University, supra note 219. 
documented knowledge of English and documented knowledge of Swedish. ${ }^{232}$ In addition, there are special requirements that applicants have completed upper secondary school courses in Swedish, English, Social Studies and History. ${ }^{233}$ There are no special entry examinations for law study. ${ }^{234}$ While admission is theoretically open to all students who meet the above-minimum criteria, nevertheless, choices must be made among otherwise qualified applicants given that only about 300 students are admitted to the law program in any one year. ${ }^{235}$ Thus, grades are important for admission. ${ }^{236}$

Similar to its American counterpart, the law school year in Sweden is divided into two separate semesters. The autumn semester extends from September to December and the spring semester from January to June. ${ }^{237}$ The full time program of study leads to a Juris Kandidat (translated in English to Master of Laws) degree and encompasses 180 credits over a four and one-half year period (nine semesters). ${ }^{238}$ The program has three distinct components ${ }^{239}$ consisting of (1) compulsory courses (totaling 140 credits), (2) optional courses $^{240}$ (totaling 20 credits) and (3) Masters Thesis ( 20 credits). Most of the classes are presented as formal lectures in large classrooms with very little dialogue between student and teacher. ${ }^{241}$ Generally, since student participation

232. See Democratic Traditions, at http://www.lysator.liu,se/Nordic/scn/faq727.html (last visited Jan. 25, 2003). Secondary or high school in Sweden is called Gymnasier and consists of a three-year program of study which is the minimum qualification necessary for graduates to continue studies at university. See id. There are some rare private schools in Sweden usually affiliated with some religion or educational philosophy. See id. Parents rarely send their children to private school; however, they can receive government financing equivalent to $80 \%$ of the municipality's average cost per pupil when they do. See id.

233. See 1999-2000 Lund Information Bulletin, at 16.

234. See Lund University, supra note 219.

235. To a large extent the number of students admitted is dictated by the state. Universities are funded through the State via a rather complicated formula based on the number of students in each particular discipline which, in turn, is established by the state.

236. See Lund University, supra note 219 . Again, while the University of Lund is being used as an example, each law faculty at the other four universities generally apply the same criteria and accept the same number of students. See Legal Studies, supra note 214.

237. See Lund University, supra note 219.

238. See id.

239. See 1999-2000 Lund Bulletin. Following is a list of the courses by semester:

1. Introduction to Law and Constitutional Law

2. Foundations of Private Law

3. Private Law - The Social Dimension. Land Use. and Environmental Law

4. Corporate Law and Revenue Law: The Economic Dimension

5. Criminal Law and Legal Procedure

6. International Law and Comparative Law

7. Legal Theory and Method

8. \& 9. Optional Courses and Masters Thesis

Id.

240. Optional courses are roughly equivalent to elective courses in U.S. law schools.

241. As of June 2001, the University of Lund Law Faculty has seventeen full professors and about twenty-three teaching assistants. See Lund University, supra note 219 . The position of Professor of Law is difficult to attain and very prestigious at universities in Sweden. The 
in class is not encouraged, there is really no incentive for a student to prepare. ${ }^{242}$ There is usually a written examination at the end of each course but little feedback before then.

Upon successful completion of the four and one-half year law program, the graduate will receive a Master of Laws degree and is prepared to embark on a choice of various careers within the Swedish legal system. There are no separate licensing tests or other requirements equivalent to the American Bar Examination.

Similar to other legal education systems the student who has performed at the highest level in law school will be in the best position to take advantage of the most prestigious and lucrative career choices. ${ }^{243}$ For example, only students in approximately the top ten percent of the class will be offered law clerk positions in the judicial training hierarchy. These positions are not only

number of actual positions is controlled by the state and does not increase on a regular basis. Consistent with the overall philosophy of legal education in Sweden and other civil law countries, a Professor of Law, while required to spend some time teaching, is primarily required to engaged in scholarly research and writing. See GLENDON ET AL., supra note 49, at 160. Publication is the sine qua non of the Professor in Sweden. See id. Historically, in a civil law system the legal scholars have enjoyed the same status as eminent jurists of the common law who are credited with creating and propagating the principles of law that form the nucleus of our common law system. See id. Civil law scholars dating back to Gaius, Grotius, Pufendorf, and others are as responsible for the development of the civil law as Coke, Marshall, Holmes and the like are responsible for the common law development. See id. While the importance of the scholar vis-a-vis the legislator in the civil law system has changed somewhat in modern times, the scholar, nevertheless, remains a very important actor in the continuing development of the civil law. See id. Law professors in Sweden today continue as the scholars that carry their predecessors' torch in this regard and are accorded commensurate prestige. See id. While the professors teach some classes, most are taught by the teaching assistant. Teaching assistants are law school graduates who are working toward completion of a major research and writing project sufficient to satisfy requirements for a $\mathrm{Ph} . \mathrm{D}$. degree and a subsequent career in legal education. See Lund University, supra note 220. The ultimate objective of the teaching assistant is to complete the $\mathrm{Ph}$.D. requirements and receive an appointment as a professor at one of the five law faculties. There are no guarantees that this will ever happen as the number of Professorships is set by the state and limited in number. Thus, unless there is some attrition it is unlikely that a candidate will be awarded a Professorship. Once the position is attained the individual can remain at the rank for life. Many teaching assistants spend the bulk of their career as salaried Lecturers at the university awaiting the elusive appointment.

242. There are, of course, some exceptions. Some courses are designed as tutorials and there is a movement to offer some courses offering students the opportunity to participate directly. See Lund University, supra note 219. In addition, as mentioned above, an attempt is being made to integrate more practical skills into the curriculum. See id. One example of this can be found in the first-year mandatory course in Foundations of Private Law in University of Lund Law Faculty curriculum. See Lund Bulletin, at 17. Part of the description of that course indicates that students will be given opportunities to practice both oral and written presentation. See id. Another compulsory course in the fifth semester of the program at the University of Lund entitled "Legal Procedure" also offers students an opportunity to make oral and written presentations as well as "legal argumentation and interpretation of case law." Id. at 18.

243. All five university law faculties in Sweden have approximately equal prestige value and thus, unlike their American counterparts, Swedish law graduates need not be concerned about this issue. 
necessary for those who wish to make a career in the judiciary, but they also provide the best entry-level training opportunities for those who wish to become Advokats. In addition, employment in an Advokat's office is generally limited to the higher ranked students.

\section{B. Advokat ${ }^{244}$}

In addition to the other available options, a young Swedish law graduate may choose at the outset of his or her career to become a member of the Swedish Bar Association, i.e. "Advokat." ${ }^{\text {"245 }}$ In general, the requirements for admission as an Advokat include that an applicant must have a Juris Kandidat degree, five years practical experience of which three must be in an Advokat's office and courses in ethics and professional techniques. ${ }^{246}$ As of 1999, in a country that graduates approximately 1200 students with law degrees each year, there were as few as 3500 Advokats in the entire country. ${ }^{247}$ In a country with a population of approximately 8.8 million people this results in a ratio of 2514 people to one Advokat. This small number is not very surprising given the cultural factors of the Swedish people mentioned above and the added fact that, technically, one does not have to be an Advokat to practice law in Sweden. In fact, while the ratio is interesting, there are probably few

244. See The Swedish Bar Association, supra note 214. The word "Advokat" as used in the Swedish legal system is a special designation for a lawyer who is a member of the Swedish Bar Association. See id. While the Advokat will represent clients in court as an advocate, they hold no special monopoly to do so. See id. Throughout this article when reference is made to Advokat, it is designed to identify a member of the Swedish Bar Association.

245. See the Swedish Bar Association, supra note 214. The Swedish Bar Association started in 1887 as a voluntary organization of academically educated advocates. See id. In 1947, it was chartered by the Crown as a quasi-public legal entity and, thus, took on official status. See id. The general structure of the Association is contained in the Swedish Code of Judicial Conduct, c. 8.

246. See Jacobsson, supra note 62, at 498. Membership requirements, as specified in SCJP, are more specific:

(1) Swedish citizenship or citizenship in a state within the European Economic Area; (2) Domicile in Sweden or another state within the European Economic Area; (3) Juris Kandidat Degree (must have passed all proficiency exams prescribed for competency to a judge's office); (4) five years of law practice in an Advokat's office, at least three of which must be "devoted to professionally assisting the general public in legal matters, either as an associate to an Advokat or a legal aid office as a sole practitioner, and at the time of the application is assisting the public in such a manner, and has taken preparatory courses in ethics and the professional techniques of a lawyer"; (5) applicant must be "known for integrity"; and (6) "is otherwise suitable to carry out the profession of a lawyer."

SCJP, supra note 76 , at c. 2 par. 1-3.

247. See Swedish Bar Association website, supra note 214. Professor Modeer maintains that "Americanization" of the Swedish legal profession has resulted in an increase in the number of law school graduates who seek membership into the Swedish Bar Association, hoping to facilitate a career in the private sector of law practice. See Modeer, supra note 9, at 52. 
meaningful inferences regarding the Swedish legal system that can be drawn from it.

The only two distinctions that an "Advokat" has over others who practice law is that only he or she can officially use the title "Advokat" and only he or she can be appointed by the court as public defense counsel in criminal cases. ${ }^{248}$ Otherwise it appears there is no difference between the Swedish Bar Association Advokat and any other person who is in the business of representing clients as an advocate in court proceedings or otherwise. In fact, one could argue that there are more disadvantages to being an Advokat than to not being one. For example, an Advokat may not serve as a professional judge, officer of the court, public prosecutor, or enforcement officer while a member of the Bar Association. ${ }^{249}$ In addition, an Advokat may not be employed by the state (which includes being a member of a law faculty), or a municipality and simultaneously be a member of the Bar Association. ${ }^{250}$ This means that if one accepts appointment as a member of a state university law faculty, one must resign from the Bar Association and refrain from identifying oneself as an Advokat. Unlike others who might be practicing law in Sweden, an Advokat is bound by a Code of Ethics and is subject to discipline, including loss of membership in the Association for violating the rules therein. ${ }^{251}$ Further, an Advokat's bookkeeping is subject to inspection and he or she may be required to submit periodic statements to the Board of the Bar Association for review. ${ }^{252}$

As a practical matter, however, there clearly seems to be an amount of prestige that attaches to the title Advokat in Sweden. In addition, anecdotally, it is suggested that people are more likely to seek the assistance of an Advokat to represent them if they must go to court.

\section{Code of Conduct for Lawyers}

As mentioned previously, the Code of Conduct is not universally applicable to members of the legal profession, but rather, applies only to those who are members of the Swedish Bar Association. Chapter eight of the Code of Judicial Conduct sets forth the general requirements and standards for both the Swedish Bar Association and its Advokat members. Section four of Chapter eight of the Code provides, among other things, that "[a]n advocate shall in his practice honestly and diligently perform the assignments entrusted to him, and shall always observe good advocate mores."253

248. See Jacobsson, supra note 62 , at $498-99$.

249. See SCJP, supra note 76 , at c. $8, \S 2$.

250. See id.

251. See id. c.8, § 4 .

252. See id. c.8, §6.

253. See id. 
In 1984 the governing Council of the Bar Association adopted more detailed rules of ethics in order to carry out the generalized requirements of the Code of Judicial Procedure and provide guidance to its members in this regard. ${ }^{254}$ It is made clear in the rules that they are not intended to be allinclusive. ${ }^{255}$ Members are admonished not to believe they are free to do anything that is not specifically forbidden therein. ${ }^{256}$

It is important to reiterate that only Advokats are bound by this Code of Conduct. ${ }^{257}$ There is no general Code of Conduct applicable to others trained as lawyers nor do they appear to be held to any higher standard of morality. There are no special courses in the law school curriculum on ethics or standards of conduct. ${ }^{258}$ In addition, the major sanction for engaging in wrongful or dishonest conduct is removal from membership in the Association. ${ }^{259}$ In theory this means that they may no longer receive court appointments in criminal cases and may not identify themselves as Advokats. However, it does not prohibit them from acting as lawyers in general.

Major provisions in the Swedish Code of Conduct provide: lawyers must include the word Advokat as part of their business name; ${ }^{260}$ advokats may advertise as long as it is correct and truthful; ${ }^{261}$ advokats are prohibited from direct in-person solicitation, ${ }^{262}$ advokats may not split fees with other persons for procuring work for them, ${ }^{263}$ advokats are bound by a rule of confidentiality which prohibits them from revealing anything which has been confided to them by the client or which they learn in connection with the confidence they may have received from the client; ${ }^{264}$ and an advokat's fee must be reasonable and if a client objects to the fee the Advokat must submit to arbitration conducted by a mechanism provided by the Bar Association. ${ }^{265}$

There is a provision in the Code that provides Advokats are not obligated to verify the correctness of information given to them by their client. ${ }^{266}$ An Advokat may not give information in proceedings before a court which he

254. See Introduction, in Code of Conduct for Lawyers (Swedish Bar Association, Nov. 9, 1984) [hereinafter Code of Conduct). The Introduction to the Rules of Conduct makes it quite clear that the rules are considered to be aimed at providing "guidance to members of the Association." Id.

255. See id.

256. See id.

257. See id.

258. See generally Lund University, supra note 219.

259. See Jacobbson, supra note 62, at 499.

260. See Code of Conduct, supra note $255, \S 3$.

261. See id. \$5.

262. See id. $\S 6$.

263. See id. $\$ 8$.

264. See id. \$ 19.

265. See id. $\$ 25$.

266. See id. Code of Conduct, supra note $254, \S 45$. 
knows not to be true nor can he contest information in court that he knows to be true. ${ }^{267}$

\section{Judiciary}

Technically, all Swedish citizen law school graduates are eligible to apply for a law clerk position in one of the general or administrative courts located throughout the country. ${ }^{268}$ Realistically, only the brightest graduates will be invited to begin the two-year training period initially as a recording clerk either at the district court itself, the office of the prosecutor, or the office of an enforcement authority. ${ }^{269}$ At some point during the first year of training, the law clerk most likely will be appointed by the Chief Judge of the court to actually sit and adjudicate certain minor matters. ${ }^{270}$ After the two-year training period the law clerk who wishes to continue on the track to become a professional judge can apply for a position as a reporting clerk on one of the courts of appeal. ${ }^{271}$ In this position he or she will continue to spend time in the district court as well as the Supreme Court. ${ }^{272}$ The law clerk will continue in this capacity until appointed by the government to a permanent professional judge position. ${ }^{273}$

\section{E. Government Service}

Sweden is no different from many civil law systems where large numbers of law school graduates enter government service. Sweden, with its extensive network of administrative authorities and agencies at the state, regional and local levels, provides numerous and varied career opportunities for young law school graduates. ${ }^{274}$ The more popular government positions available are criminal investigator and prosecutor.

267. See id.

268. See Marcusson, supra note 93, at 547; Jacobsson, supra note 117, at 502.

269. See Marcusson, supra note 93 , at 547 ; see also Stromholm, supra note 15 , at 43 . The district courts in Sweden are different in many ways from American courts of first instance. For example, the Swedish district courts perform many functions that lawyers, or even banks, might perform in the American legal system such as transfers and mortgages of land, registration of wills and inventories of decedent's estates, as well as supervision of guardianships of minors. See id.

270. See Jacobsson, supra note 117 , at 502.

271. See id.

272. See id.

273. See id.

274. See Nergelius, supra note 25 , at 74. 


\section{Criminal Investigator}

Along with the courts, the police and prosecution authorities are an integral part of the Swedish criminal justice system. ${ }^{275}$ A career option available to a law graduate is as a criminal investigator with the police authority. The university law degree is a prerequisite to training for this position. In 1991, there were 700 applicants who applied for the policeinvestigator training program and thirty were accepted. ${ }^{276}$ The three-year training program takes place at the Police College and includes courses in, among other things, analysis and planning, administration and workplace psychology. ${ }^{277}$ Also included is field work throughout the criminal justice system with the police, courts, and prosecutor's office. ${ }^{278}$

\section{Prosecutor}

Sweden has a National Prosecution Authority under the direction of a Prosecutor-General, who is appointed by the government and responsible for the oversight of the entire prosecutorial system. ${ }^{279}$ For purposes of criminal prosecution, the country is divided into region, county and district authorities. ${ }^{280}$ Each region is headed by a Director of Public Prosecution, who is appointed by the government and who is also responsible for overseeing a network of prosecutorial offices located throughout the region. ${ }^{281}$ It is in these offices where all criminal cases are processed by a staff of public prosecutors. ${ }^{282}$ As mentioned previously, public prosecutors are responsible for conducting the preliminary police investigation, making decisions on whether to prosecute in a given case, and representing the state before the court in criminal trials. ${ }^{283}$

Public prosecutors must have a law degree and, thus, this career path is often chosen by young law graduates. Training begins either immediately upon graduation from university or after a short period as a judicial law clerk.

275. See Jacobsson, supra note 117 , at 499.

276. See National Council for Crime Prevention, supra note 171.

277. See id.

278. See id.

279. See SCJP, supra note 76 , at c.7, \& 2 .

280. See Jacobsson, supra note 101 , at 500 .

281. See SCJP, supra note 76 , at $c .7, \S 2$. Each prosecutorial region contains several prosecution "chambers" which are roughly analogous in design and jurisdiction to a District Attorney office in the United States.

282. See Jacobsson, supra note 117 , at 500 .

283. See id. 


\section{F. Private Practitioners}

As mentioned at other points in this article, one does not have to have a degree in law or be an Advokat to be a private legal practitioner in Sweden. Thus, at least in theory, anyone can put out a shingle and take on clients. Of course, as a practical matter, unless someone has developed a particular expertise in an area and a certain amount of notoriety, it is unlikely that they will attract many clients.

Certainly a law school graduate can begin a practice in this same fashion with perhaps a bit more credibility and chance for success. In Sweden the legal profession is not officially bifurcated, unlike civil law countries such as France and Germany which, officially divide the legal profession into, inter alia, notaries and advocates. ${ }^{284}$ Technically any law graduate or other person in Sweden can represent a client in any legal matter in or out of court, except as a court appointed defense counsel. ${ }^{285}$ Some law graduates find their way to the more established law offices and begin their careers as aspiring practitioners. Few graduates begin their professional life as solo practitioners without gaining some modicum of experience elsewhere.

\section{CONCLUSION}

The fundamental structure, methods of thought, and attitudes toward the law in the Swedish legal system are rather unique and historically well suited to her social, cultural, and historical development. However, her entry into the European Union and other changes rapidly occurring both at home and abroad will require that she assume a more international focus and demand some changes in her internal legal culture. These changes have already begun. Increased human rights protections at home and free movement of goods and people throughout the European Community are placing new demands on the courts and members of the legal profession. Courts are beginning to assume a more active role in the governmental structure and more law students are seeking careers with law firms in the private sector. Changes in the legal culture will be necessary if there is to be a successful transition. Change will not come easily and all actors in the legal system, from the legal educators, scholars, students, and lawyers to the judges, will need to make adjustments. Perhaps the most important of these adjustments will require a re-education of the profession to encourage a more positive and politically active self-image.

284. See GLENDON ET AL., supra note 49, at 153. In these systems the notary is a powerful, important person, in contrast to the same position in the United States. For example, among other things, a notary may have primary responsibility for drafting certain documents such as marriage contracts, wills, mortgages etc. See id.

285. As a practical matter, lawyers in Sweden are no different than lawyers in other countries with a unified bar in that they naturally tend to divide between those who litigate and those who advise. 
